1. Final Report

U.S. Department of Energy

\title{
Characterization of Contaminant Transport using Naturally- Occurring U-Series Disequilibria
}

\author{
LANL PI: Michael Murrell (CST-11, Los Alamos National Laboratory) \\ LANL Collaborator: Robert Roback (E-ET, Los Alamos National Laboratory) \\ Campus PI: T.L. Ku (USC) \\ Campus Collaborator: S. Luo (USC)
}

Project Number: 54741

Project Duration: 8/96-9/99 


\section{Table of Contents}

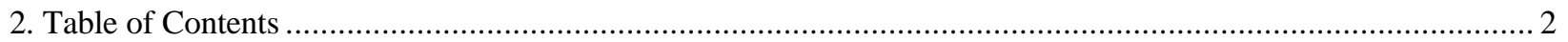

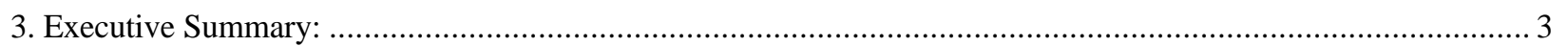

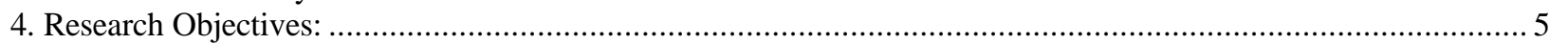

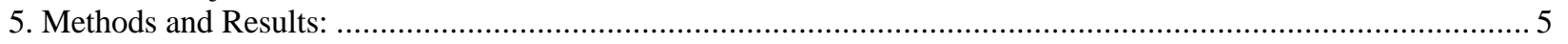

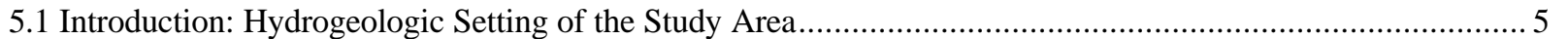

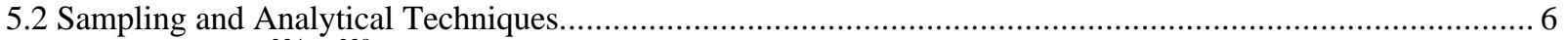

5.3. Application of ${ }^{234} \mathrm{U} /{ }^{238} \mathrm{U}$ Ratios to Deduce Flow Patterns and Groundwater Evolution.................................... 7

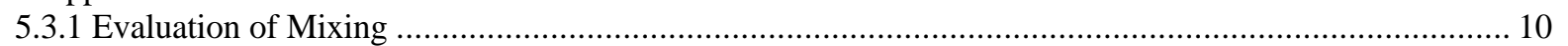

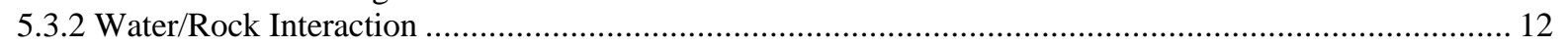

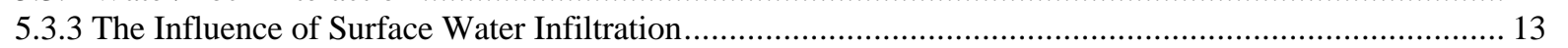

5.4 Application of the Short-Lived Uranium-Series Nuclides to Deduce Flow Patterns and Groundwater Evolution

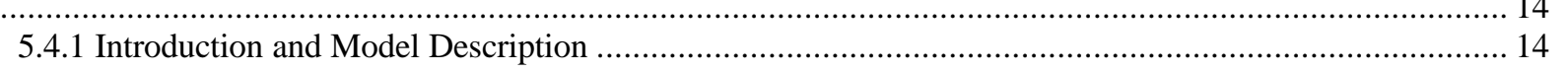

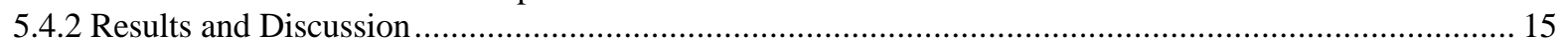

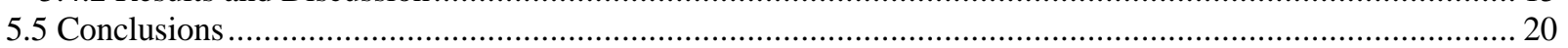

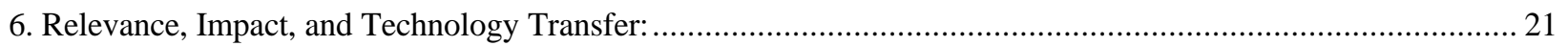

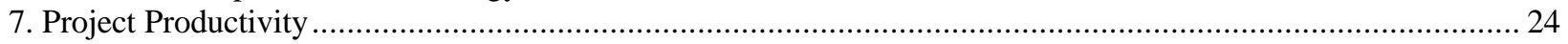

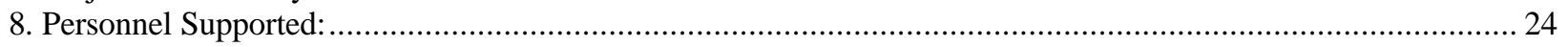

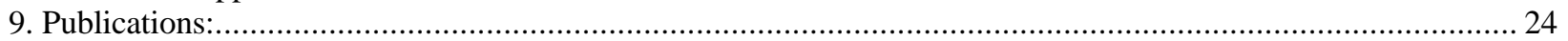

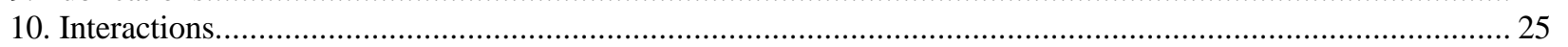

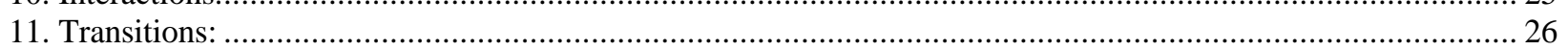

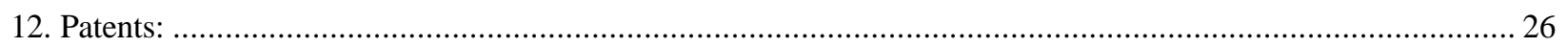

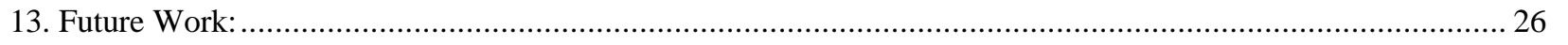

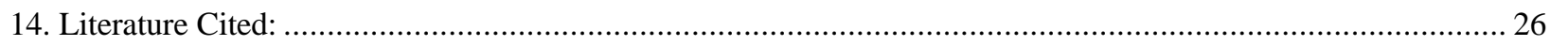

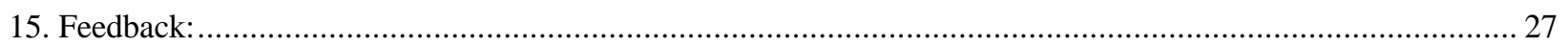

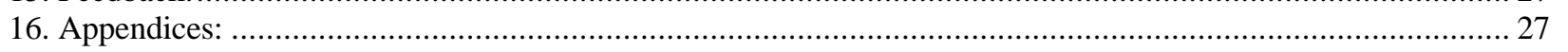

A. Luo, S., Ku, T. L., Roback, R., Murrell, M., and McLing, T. L., In-situ radionuclide transport and preferential groundwater flows at INEEL (Idaho): Decay-series disequilibrium studies .................................................22

B. Roback, R.C., Johnson, T.M., McLing T.L., Murrell, M.T., Ku, T. L, and Luo S., Preferential flow pathways and groundwater evolution in the Snake River Plain aquifer in the vicinity of the INEEL: constraints form

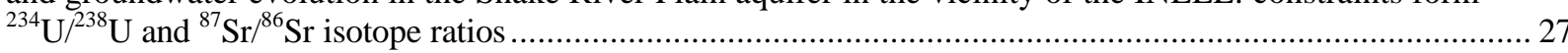

C. Johnson, T.M., Roback, R.C., McLing, T.L., Bullen, T.D., DePaolo, D.J., Doughty, C., Hunt R.J., and Murrell,

M.T., Groundwater "fast paths" in the Snake River Plain Aquifer: radiogenic isotope ratios as superior natural

groundwater tracers 


\section{Executive Summary:}

Groundwater flow can be very heterogeneous in fracture-dominated aquifers resulting in large differences in relative flow velocity, residence time and the extent of water/rock interaction. In fracture-dominated aquifers, the difficulties in predicting such flow heterogeneity introduce significant uncertainty in predicting transport of contaminants and for groundwater management. Naturally occurring isotopes of the uranium-series decay chain can be excellent tracers of groundwater flow and geochemical evolution and can provide information that is not provided by more commonly utilized chemical and isotopic data. In this study, we examined naturally-occurring uranium-series isotopic ratios in a fresh-water, fracture-flow aquifer, the eastern Snake River Plain aquifer, and coupled these results with strontium isotopics and solute concentration data. These results provide important information that clearly reveals details of groundwater flow patterns and geochemical evolution of the aquifer at INEEL.

Previous studies at the INEEL utilizing head data, major element solute data and anthropogenic tracers have provided a consistent, yet generalized picture of aquifer flow patterns and geochemical evolution. By using natural-occurring uranium-series nuclides, we have provided a more detailed groundwater flow pathways, mixing volumes and water/rock interaction, and prediction of solute migration rates at INEEL. Two zones of preferential flow were identified that represent pathways along which groundwater from the Birch Creek and Little Lost Rivers is preferentially channeled. Conversely, two zones of relatively stagnant groundwater were identified. Modeling $\mathrm{U}$ and Th series disequilibria in the groundwater at INEEL placed constraints on the following in-situ parameters: (1) time scales of sorption (minutes for Ra and $\mathrm{Th}$ ), desorption (days for Ra and years for $\mathrm{Th}$ ), and precipitation (days for Th, years for Ra, and centuries for $U)$; (2) retardation factors due to sorption $\left(>10^{6}\right.$ for ${ }^{232} \mathrm{Th}$, 
$\sim 10^{4}$ for ${ }^{226} \mathrm{Ra}$, and $\sim 10^{3}$ for $\left.{ }^{238} \mathrm{U}\right)$; (3) dissolution rates of rocks ( 70 to $\left.800 \mathrm{mg} / \mathrm{L} / \mathrm{y}\right)$; and (4) groundwater transit time ( $<10$ to $\sim 90$ years). Groundwater chemistry and the size and density of microfracture in rocks exert an important control on the retardation factors, precipitation and dissolution rates, and $\alpha$-recoil rates of the radionuclides in these groundwaters.

Studies of radionuclide transport in geologic systems based on naturally occurring decayseries disequilibria, such as the multiple-tracer approach of the present study, have the advantage of obtaining in-situ hydrologic information integrated over a range of timescales. This study provides a clearer picture of the physical and chemical hydrology of the Snake River Plain aquifer beneath INEEL than was previously available. This information is proving to be extremely valuable to environmental management projects at the INEEL, such as those underway by the USGS. Methods developed as part of this study have been applied at Rocky Flats and could be applied at other sites to characterize the physical and chemical hydrology. Such information is invaluable, particularly at sites where expensive groundwater remediation is being undertaken or considered. 


\section{Research Objectives:}

Geologic heterogeneity plays an important role in transporting contaminants in fractured rocks. Preferential flow paths in the fractured rocks act as a major pathway for transport of radioactive contaminants in groundwaters. The weathering/dissolution of rock by groundwater also influences contaminant mobility. Thus, it is important to understand the hydrogeologic features of the site and their impact on the migration of radioactive contaminants. In this regard, quantification of the rock weathering/dissolution rate and fluid residence time from the observed decay-series disequilibria is valuable. By mapping the spatial distribution of the residence time of groundwater in fractured rocks, the subsurface preferential flow paths (with high rock permeability and short fluid residence time) can be determined.

This research project is directed toward a quantitative assessment of contaminant transport rates in fracture-rock systems using uranium-series radionuclides. Naturally occurring uranium- and thorium-series radioactive disequilibria provide information on the rates of adsorption-desorption and transport of radioactive contaminants as well as on fluid transport and rock dissolution in a natural setting. This study also provides an improved characterization of preferential flow and contaminant transport at the Idaho Environmental and Engineering Laboratory (INEEL) site. We have produced a realistic model of radionuclide migration at the INEEL site, taking into account the retardation processes involved in the rock/water interaction. The major tasks were to (1) determine the natural distribution of $\mathrm{U}, \mathrm{Th}, \mathrm{Pa}$ and $\mathrm{Ra}$ isotopes at the site, and (2) study rock/water interaction processes using U/Th series disequilibrium and a statistical analysis-based model for the calculation of in-situ retardation factors of radionuclides and rock/water interaction timescales. This work was undertaken with the collaboration and cooperation of the USGS.

The uranium and thorium decay series can be applied to the study of transport because they contain several isotopes of the same elements with different decay half lives. This allows simultaneous solutions to the mass-balance model equations for all isotopes of an element that in turn provides information on parameters such as residence time of fluid in the fractured rock, surface area and permeability, and dissolution rate of the rocks. By using decay-series disequilibria as a natural analog to contaminant transport, the combined effect of variable speciation associated with formation of colloids and organic compounds are taken into account, and the sorption capacity and retardation factors determined by this approach are site-dependent. Because the U- and Th-decay series exhibit elements with a range of chemical properties, one may use the analog approach to simultaneously assess the migration of different radioactive wastes containing transuranic, as well as alkali-, alkali earth, and lanthanide elements, in groundwater systems.

\section{Methods and Results:}

\subsection{Introduction: Hydrogeologic Setting of the Study Area}

The Eastern Snake River Plain aquifer in Southern Idaho (Fig. 1) is one of the nations largest and is the major source of water for drinking and agriculture in the region. Most of the recharge to the aquifer is from precipitation along the continental divide to the northeast and from the Snake River and its tributaries on the northeastern and eastern edge of the aquifer. Also important in the vicinity of the INEEL (Figs. 1 and 2) is recharge from the Birch Creek, Little Lost River and Big 
Lost River Valleys to the north and west of the site. Regional flow in the aquifer is from the northeast to the southwest; groundwater is discharged in a series of large springs between Twin Falls and Hagerman (Fig. 1).

The Idaho National Engineering and Environmental Laboratory (INEEL) is a Department of Energy facility that encompasses approximately $2300 \mathrm{~km}^{2}$ in the west-central part of the Eastern Snake River Plain (Figs. 1 and 2). Since the early 1950's, low-level radioactive and nonradioactive waste was disposed of via injection wells that penetrate to the aquifer. Contaminant plumes extend down gradient from these injection wells and some contaminants can be tracked to near the southern boundary of the site (e.g. Bartholomay et al., 1995). In addition, there are several surface and shallowly buried waste storage sites that have released contaminants to the environment. Concerns about existing and potential additional contamination of the aquifer have prompted numerous studies to better understand groundwater flow and contaminant migration in the aquifer (e.g. Welhan and Reed, 1997; Beasley, et al, 1998 and references therein; this study).

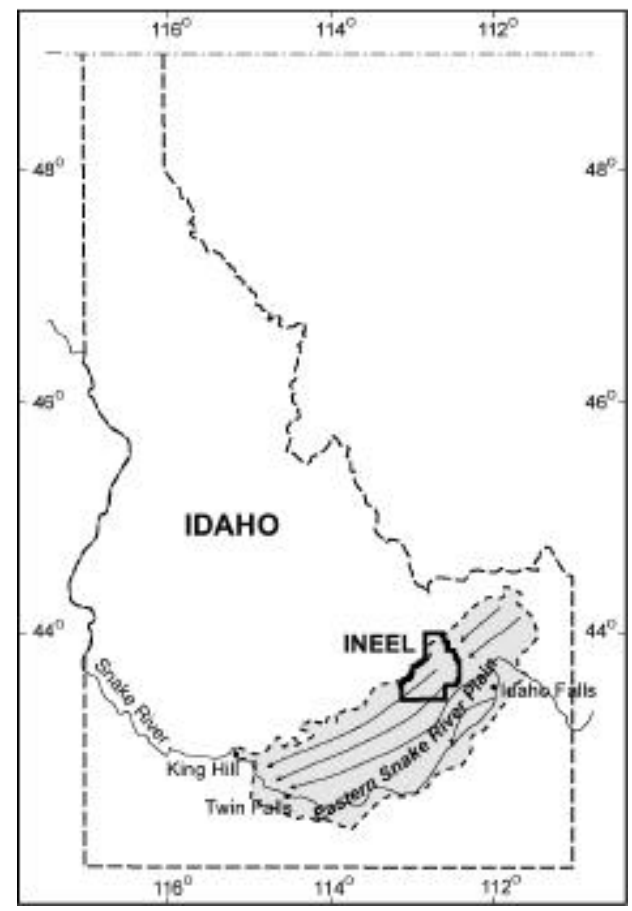

Figure 1. Map of Idaho showing the eastern Snake River Plain aquifer and the location of the INEEL. Arrows show principal flow directions.

\subsection{Sampling and Analytical Techniques}

Sixty-six groundwater samples, one river sample and one hot spring sample collected within or near the INEEL were analyzed for uranium isotopic composition and concentration. Most of these samples were also analyzed for strontium isotopic composition and concentration as well as major cations as part an EMSP-funded project (Johnson et al, Appendix C). Thirteen samples were collected on two separate occasions spanning up to 27 months between sampling to test for short-term variability. Most of the samples are from the upper part of the aquifer therefore 
minimizing potential chemical variability due to depth. Water samples from local hot springs and available deep wells were also analyzed to help constrain potential effects of deep-water input.

Twenty-three of the wells sampled for uranium measurements were also sampled for the full suite of uranium-series nuclides. To overcome unexpectedly low concentrations of some of the uranium-series nuclides in these samples, we developed an in-situ filtration-enrichment sampling system that allowed us to obtain large-volume samples ( 1000 liters). Radioisotopes of thorium $\left({ }^{232} \mathrm{Th},{ }^{230} \mathrm{Th},{ }^{228} \mathrm{Th}\right.$, and $\left.{ }^{234} \mathrm{Th}\right)$, radium $\left({ }^{226} \mathrm{Ra},{ }^{228} \mathrm{Ra}\right.$, and $\left.{ }^{224} \mathrm{Ra}\right)$, polonium $\left({ }^{210} \mathrm{Po}\right)$, and lead $(210 \mathrm{~Pb})$ were pre-concentrated in the field by passing the samples through two cartridge filtration units (connected in series at each well) containing $\mathrm{MnO}_{2}$-impregnated acrylic fiber adsorbers. Small-volume samples were also collected for ${ }^{222} \mathrm{Rn}$ by alpha scintillation counting. These 23 samples span the range of chemical variations observed in the area and also provide a broad geographic coverage of wells in the site.

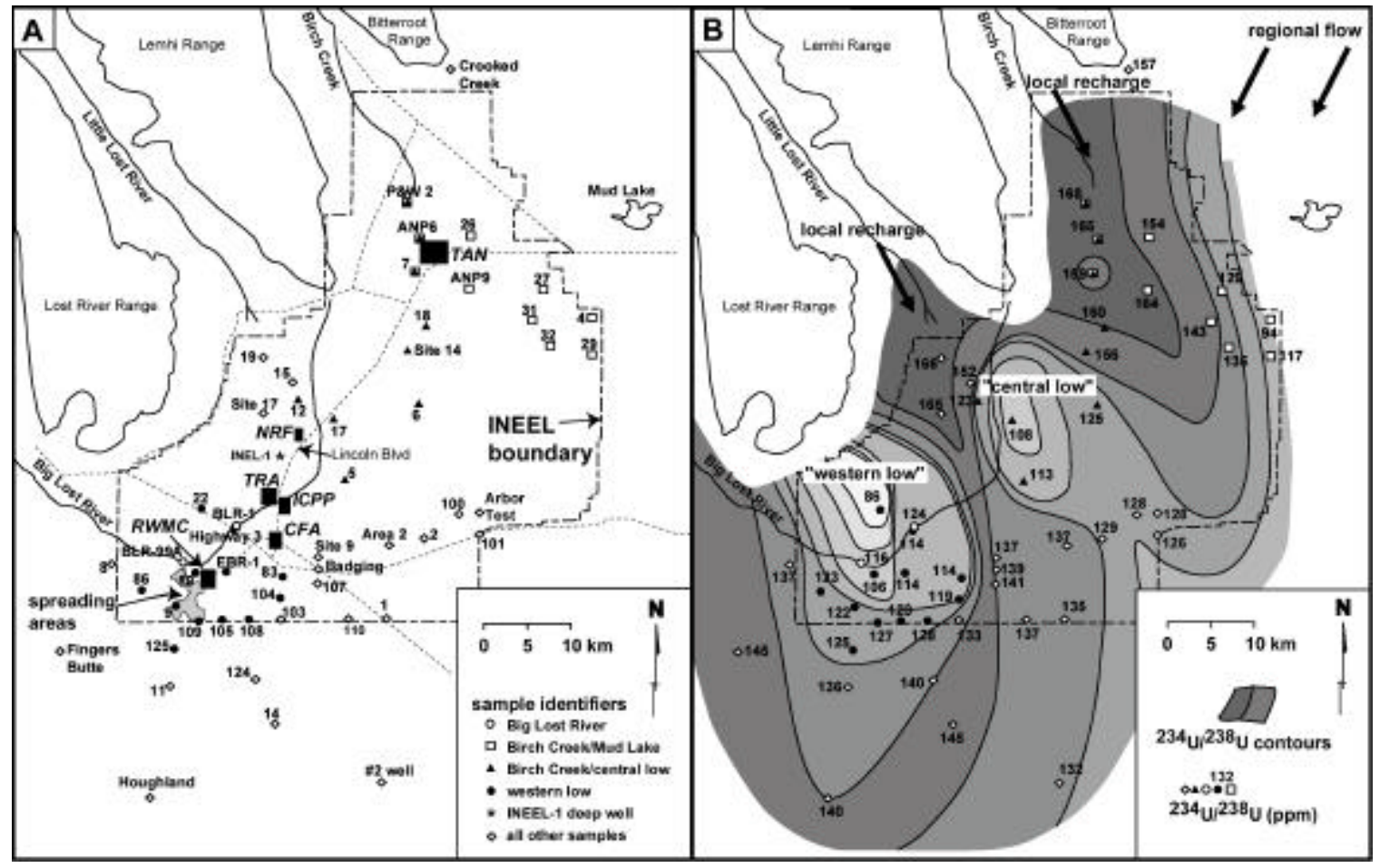

Figure 2. Maps showing INEEL and vicinity. (A) Shows important features discussed in text and well identifiers for samples used in this study. (B) Shows measured ${ }^{234} \mathrm{U} /{ }^{238} \mathrm{U}$ atomic ratios in parts per million (ppm) and a hand contour of those values for all aquifer samples. Contour intervals are >160, 160-140, 140-130, 130$120,120-110,110-100,<100$. Symbols used delineate sample groupings discussed in the text and also in Figures 3 and 4.

\subsection{Application of ${ }^{234} U{ }^{238} U$ Ratios to Deduce Flow Patterns and Groundwater Evolution}

Groundwater uranium concentrations (Table 1) range from 0.19 to $3.59 \mathrm{ppb}$, values that are typical for oxidizing groundwater (Osmond and Cowart, 1992). Uranium concentrations do not show a patterned geographical distribution. Groundwater that emanates from the Little Lost 
River and Birch Creek Valley has uranium concentrations that are similar to those of the regional aquifer. Comparisons of uranium concentration with concentration of major cations, or cation ratios show no consistent correlation. Uranium concentrations for INEL-1 collected at a depth of 10,300 feet and for Condie Hot Spring (0.19 and 0.03 respectively) are the lowest values measured. This is consistent with the removal of uranium in response to the more reducing conditions expected at depth.

The INEEL has a long history of producing and disposing of isotopically modified uranium and uranium with non-natural isotopic composition has been detected in the aquifer downgradient from the ICPP deep disposal well (Beasley et al, 1998). Although most of the samples analyzed in this study were collected far from possible contamination, a few of the samples do have the potential to contain non-natural uranium. For this reason, all samples that are within or near the contaminant plume extending south of the ICPP (e.g. Beasley et al, 1998), as well as a survey of other samples, were examined for the presence of ${ }^{236} U$ and for non-natural ${ }^{235} U /{ }^{238} U$. All of these samples had natural ${ }^{235} \mathrm{U} /{ }^{238} \mathrm{U}$ ratios and no ${ }^{236} \mathrm{U}$ was detected. In some of the samples, the apparent lack of ${ }^{236} \mathrm{U}$ may be due to the low sample volumes $(\sim 100 \mathrm{ml})$ analyzed for this study. The data demonstrate that the measured ${ }^{234} \mathrm{U} /{ }^{238} \mathrm{U}$ isotopic ratios represent natural values.

Table 1. Uranium concentration and isotopic composition.

\begin{tabular}{|c|c|c|c|c|c|c|c|}
\hline Sample & Date Collected & Latitude & Longitude & $\begin{array}{c}\mathrm{U} \\
(\mathrm{ppb}) \\
\end{array}$ & $\begin{array}{l}(+/-) \\
(\%) \\
\end{array}$ & $\begin{array}{c}234 / 238 \\
(\mathrm{ppm}) \\
\end{array}$ & $\begin{array}{l}(+/-) \\
(\%) \\
\end{array}$ \\
\hline USGS 1 & $4 / 21 / 97$ & 43.4500 & 112.7856 & 1.70 & 0.32 & 134.6 & 0.39 \\
\hline USGS 1 LVS & $8 / 31 / 98$ & 43.4500 & 112.7856 & 1.72 & 0.24 & 134.0 & 0.14 \\
\hline USGS 1 duplicate & $8 / 31 / 98$ & 43.4500 & 112.7856 & 1.72 & 0.23 & 133.8 & 0.21 \\
\hline USGS 2 LVS & $8 / 26 / 98$ & 43.5556 & 112.7231 & 1.82 & 0.22 & 129.0 & 0.13 \\
\hline USGS 4 & $4 / 28 / 97$ & 43.7825 & 112.4728 & 3.59 & 0.27 & 94.3 & 0.33 \\
\hline USGS 5 & $10 / 10 / 96$ & 43.5950 & 112.8269 & 1.50 & 0.22 & 112.5 & 0.13 \\
\hline USGS 6 & $7 / 16 / 96$ & 43.6753 & 112.7603 & 1.75 & 0.13 & 124.7 & 0.18 \\
\hline USGS 6 LVS & $9 / 12 / 97$ & 43.6753 & 112.7603 & 1.75 & 0.21 & 125.1 & 0.16 \\
\hline USGS 7 & $4 / 21 / 97$ & 43.8208 & 112.7442 & 2.26 & 0.23 & 158.9 & 0.12 \\
\hline USGS 8 & $10 / 8 / 96$ & 43.5225 & 113.1994 & 2.10 & 0.20 & 136.7 & 0.12 \\
\hline USGS 9 LVS & 9/1/98 & 43.4590 & 113.0777 & 1.57 & 0.21 & 122.0 & 0.12 \\
\hline USGS 11 & 10/9/96 & 43.3933 & 113.1117 & 1.67 & 0.22 & 135.8 & 0.12 \\
\hline USGS 12 LVS & $9 / 10 / 97$ & 43.6906 & 112.9186 & 2.36 & 0.26 & 123.0 & 0.21 \\
\hline USGS 14 & $4 / 10 / 97$ & 43.3386 & 112.9422 & 2.37 & 0.21 & 145.1 & 0.15 \\
\hline USGS 15 & $7 / 25 / 96$ & 43.7094 & 112.9214 & 1.78 & 0.25 & 152.4 & 0.17 \\
\hline USGS 17 & $10 / 16 / 96$ & 43.6600 & 112.8650 & 1.71 & 0.34 & 107.8 & 0.46 \\
\hline USGS 17 LVS & $9 / 11 / 97$ & 43.6600 & 112.8650 & 1.75 & 0.21 & 108.0 & 0.15 \\
\hline USGS 18 & 7/19/96 & 43.7611 & 112.7358 & 2.06 & 0.31 & 159.8 & 0.12 \\
\hline USGS 18 LVS & $9 / 12 / 97$ & 43.7611 & 112.7358 & 2.07 & 0.21 & 160.1 & 0.13 \\
\hline USGS 19 & $10 / 15 / 96$ & 43.7406 & 112.9656 & 1.56 & 0.21 & 165.4 & 0.14 \\
\hline USGS 19 LVS & $9 / 10 / 97$ & 43.7406 & 112.9656 & 1.59 & 0.21 & 166.1 & 0.12 \\
\hline USGS 22 & 7/18/96 & 43.5728 & 113.0547 & 0.33 & 0.27 & 84.9 & 0.86 \\
\hline USGS 22 LVS & $8 / 31 / 98$ & 43.5728 & 113.0547 & 0.43 & 0.22 & 85.9 & 0.16 \\
\hline USGS 26 & $10 / 15 / 96$ & 43.8694 & 112.5383 & 2.39 & 0.36 & 155.1 & 0.40 \\
\hline USGS 26 LVS & $9 / 3 / 98$ & 43.8694 & 112.5383 & 2.41 & 0.29 & 154.0 & 0.18 \\
\hline USGS 27 & $10 / 15 / 96$ & 43.8142 & 112.6000 & 3.04 & 0.19 & 129.2 & 0.10 \\
\hline
\end{tabular}




\begin{tabular}{|c|c|c|c|c|c|c|c|}
\hline USGS 27 LVS & $9 / 2 / 98$ & 43.8142 & 112.6000 & 3.10 & 0.21 & 129.4 & 0.13 \\
\hline USGS 29 & 7/19/96 & 43.7353 & 112.4808 & 2.00 & 0.21 & 117.2 & 0.24 \\
\hline USGS 31 LVS & $9 / 2 / 98$ & 43.7736 & 112.5414 & 2.27 & 0.22 & 143.4 & 0.17 \\
\hline USGS 32 & $7 / 19 / 96$ & 43.7456 & 112.5392 & 2.53 & 0.16 & 134.7 & 0.19 \\
\hline USGS 83 LVS & 8/28/98 & 43.5064 & 112.9376 & 1.37 & 0.23 & 113.6 & 0.20 \\
\hline USGS 86 & $10 / 11 / 96$ & 43.4928 & 113.1336 & 1.03 & 0.20 & 122.9 & 0.13 \\
\hline USGS 86 LVS & 9/8/97 & 43.4928 & 113.1336 & 0.99 & 0.88 & 122.3 & 0.66 \\
\hline USGS 89 & 7/17/96 & 43.5014 & 113.0586 & 1.16 & 0.27 & 105.5 & 0.30 \\
\hline USGS 100 & $4 / 28 / 97$ & 43.5842 & 112.6683 & 1.50 & 0.25 & 127.8 & 0.13 \\
\hline USGA 101 & $10 / 10 / 96$ & 43.5486 & 112.6386 & 1.32 & 0.21 & 125.4 & 0.16 \\
\hline USGS 101 LVS & 9/8/97 & 43.5486 & 112.6386 & 1.36 & 0.25 & 125.7 & 0.18 \\
\hline USGS 103 & $7 / 15 / 96$ & 43.4539 & 112.9353 & 1.49 & 0.11 & 132.5 & 0.18 \\
\hline USGS 103 LVS & 9/9/97 & 43.4539 & 112.9353 & 1.46 & 0.51 & 133.1 & 0.23 \\
\hline USGS 104A & $7 / 15 / 96$ & 43.4822 & 112.9356 & 1.52 & 0.12 & 118.9 & 0.20 \\
\hline USGS 105 & $5 / 5 / 97$ & 43.4508 & 113.0050 & 2.16 & 0.22 & 122.6 & 0.20 \\
\hline USGS 107 LVS & $8 / 27 / 98$ & 43.4950 & 112.8910 & 2.20 & 0.24 & 140.9 & 0.17 \\
\hline USGS 108 LVS & 9/9/97 & 43.4497 & 112.9739 & 1.76 & 0.21 & 127.7 & 0.19 \\
\hline USGS 109 LVS & $9 / 1 / 98$ & 43.4503 & 113.0488 & 1.73 & 0.21 & 127.0 & 0.13 \\
\hline USGS 110 LVS & $8 / 25 / 98$ & 43.4547 & 112.8375 & 2.03 & 0.21 & 137.0 & 0.12 \\
\hline USGS 124 & 4/10/97 & 43.3853 & 112.9753 & 1.61 & 0.21 & 140.3 & 0.13 \\
\hline USGS 125 & $10 / 11 / 96$ & 43.4339 & 113.0911 & 2.17 & 0.20 & 124.7 & 0.14 \\
\hline ANP 9 & 4/28/97 & 43.3853 & 112.9753 & 2.37 & 0.19 & 164.4 & 0.13 \\
\hline ANP 6 & 7/19/96 & 43.8644 & 112.7419 & 2.12 & 0.13 & 165.4 & 0.18 \\
\hline ANP 6 LVS & 9/11/97 & 43.8644 & 112.7419 & 2.25 & 0.41 & 165.1 & 0.22 \\
\hline ArborTest1 & $10 / 10 / 96$ & 43.5856 & 112.6467 & 1.69 & 0.20 & 128.2 & 0.11 \\
\hline AREA 2 & 7/18/96 & 43.5397 & 112.7839 & 1.94 & 0.16 & 136.6 & 0.17 \\
\hline Badging Facility & $4 / 10 / 97$ & 43.5117 & 112.8975 & 1.50 & 0.25 & 139.2 & 0.32 \\
\hline Big Lost River 1 & 4/10/97 & 43.5493 & 113.0069 & 2.26 & 0.22 & 123.8 & 0.14 \\
\hline Big Lost River 2 & 7/14/99 & 43.5158 & 113.0811 & 2.20 & 0.22 & 116.4 & 0.21 \\
\hline Condie Hot Spring & $7 / 16 / 96$ & 43.3342 & 113.9261 & 0.03 & 0.32 & 292.0 & 0.50 \\
\hline Crooked Creek & $7 / 23 / 97$ & 44.1742 & 112.6442 & 3.17 & 0.23 & 157.1 & 0.12 \\
\hline EBR-1 & 10/16/96 & 43.5142 & 113.0072 & 2.03 & 0.21 & 113.7 & 0.18 \\
\hline Fingers Butte & 6/3/97 & 43.3503 & 113.2853 & 1.78 & 0.22 & 144.7 & 0.13 \\
\hline Highway 3 & 4/29/97 & 43.5492 & 113.0067 & 1.89 & 0.26 & 114.1 & 0.30 \\
\hline Houghland & $6 / 3 / 97$ & 43.2581 & 113.1169 & 1.81 & 0.21 & 139.8 & 0.12 \\
\hline INEEL-1 2000' & $3 / 24 / 79$ & 43.6214 & 112.9431 & 1.88 & 0.19 & 172.7 & 0.19 \\
\hline INEEL-1 10300' & $7 / 20 / 79$ & 43.6214 & 112.9431 & 0.19 & 0.10 & 114.0 & 0.50 \\
\hline $\mathrm{P}$ and $\mathrm{W} 2$ & $10 / 15 / 96$ & 43.9053 & 112.7586 & 1.86 & 0.22 & 167.8 & 0.12 \\
\hline Site 9 & $7 / 22 / 96$ & 43.5231 & 112.8836 & 1.68 & 0.19 & 137.4 & 0.17 \\
\hline Site 14 & $8 / 20 / 96$ & 43.7261 & 112.7753 & 2.07 & 0.20 & 155.8 & 0.11 \\
\hline Site 14 LVS & $9 / 11 / 97$ & 43.7261 & 112.7753 & 2.07 & 0.23 & 155.8 & 0.15 \\
\hline Site 17 & $7 / 25 / 96$ & 43.6742 & 112.9658 & 1.43 & 0.10 & 165.3 & 0.14 \\
\hline Sturm 1 & $5 / 21 / 97$ & 44.0944 & 111.4356 & 0.93 & 0.24 & 166.0 & 0.16 \\
\hline$\# 2$ Well & $6 / 6 / 97$ & 43.2725 & 112.7889 & 1.69 & 0.72 & 132.3 & 0.60 \\
\hline
\end{tabular}

Most ${ }^{234} \mathrm{U} /{ }^{238} \mathrm{U}$ atomic ratios range between 0.000085 and 0.000168 (85 to $168 \mathrm{ppm}$, table 1 ). The only exceptions are INEL-1 from a depth of $1511-2518$ feet with a ${ }^{234} \mathrm{U} /{ }^{238} \mathrm{U}$ ratio of 0.000173 and Condie Hot Spring with a value of 0.000292. Short-term variability in uranium 
isotopic composition as determined by analysis of duplicate samples collected up to 27 months apart is insignificant.

A contour map of ${ }^{234} \mathrm{U} /{ }^{238} \mathrm{U}$ ratios (Fig. 2b) shows an interesting and informative pattern. Water entering the aquifer from the Birch Creek, Little Lost River and Big Lost River valleys to the north and west has high ${ }^{234} \mathrm{U} /{ }^{238} \mathrm{U}$ ratios relative to water originating east of the INEEL. Water masses with this distinct isotopic signature persist well away from their sources. Particularly well defined is a relatively narrow zone (the high isotope ratio zone, or HIRZ) that extends southward from the mouth of the Little Lost River valley through the southern boundary of the INEEL. A second though less pronounced zone trends southeast from the mouth of Birch Creek. Two zones with relatively low ${ }^{234} \mathrm{U} /{ }^{238} \mathrm{U}$ occur near the center of the INEEL (central low isotope ratio zone, CLZ) and in the western part of the INEEL (western low isotope ratio zone, WLZ).

A first-order observation of the data is that ${ }^{234} \mathrm{U} /{ }^{238} \mathrm{U}$ ratios are high in waters that emanate from the local recharge valleys on the northwest edge of the aquifer and lower everywhere in the basalt aquifer (Fig. 2b). This contrast in ${ }^{234} \mathrm{U} /{ }^{238} \mathrm{U}$ isotope ratios reflects the markedly different geology and hydrology of the local recharge valleys when compared to the aquifer. The observed isotopic pattern is interpreted to reflect fundamental aspects of groundwater flow.

The two high-isotope ratio zones are interpreted to represent preferential flow pathways along which groundwater from the Birch Creek and Little Lost Rivers is channeled. Isotopic modification due to water/rock interaction or mixing is minimized along these zones because of short groundwater residence times, which are further substantiated by modeling of the shortlived nuclides presented below, and/or relatively high volumes of recharge water relative to volumes from the regional aquifer. Conversely, the CLZ and WLZ are interpreted as zones of relatively stagnant groundwater that are physically isolated from the more rapid regional flow by low permeability zones. Boundaries of the CLZ and WLZ are locally quite sharp indicating minimal mixing with the regional aquifer. In the low isotope-ratio zones, the ${ }^{234} U /{ }^{238} U$ ratios of the groundwater have evolved closer to equilibrium values due to increased amounts of water rock interaction. As is discussed below, both the CLZ and the WLZ contain significant amounts of water from the Big Lost River. The combination of low initial isotope ratios of the Big Lost River and infiltration of this water through a thick vadose zone results in the lowest measured isotope ratios.

\subsubsection{Evaluation of Mixing}

Isotopic modification of $U$ reflects the combined effects of mixing and water-rock interaction; however, due to the high solubility of $U$ in this system, it is expected that mixing will be at least locally important in controlling $\mathrm{U}$ isotopic ratios. A plot of $1 / \mathrm{U}$ concentration vs. ${ }^{234} \mathrm{U} /{ }^{238} \mathrm{U}$ ratio is an effective way to evaluate mixing of water masses. The entire data set (Fig. 3) is non-linear due to the presence of at multiple end-member waters defined by distinct $U$ isotopic composition, concentration, and geographic distribution as well as variable degrees of water rock interaction. Possible end-member waters for the system include groundwater from the Birch Creek and Little Lost River valleys, groundwater from the regional aquifer, and infiltrated surface water from the Big Lost River and irrigation, and upwelling thermal water. When examined in detail, however, isotope/element relations across some isotope gradients reveal that mixing is important locally. 


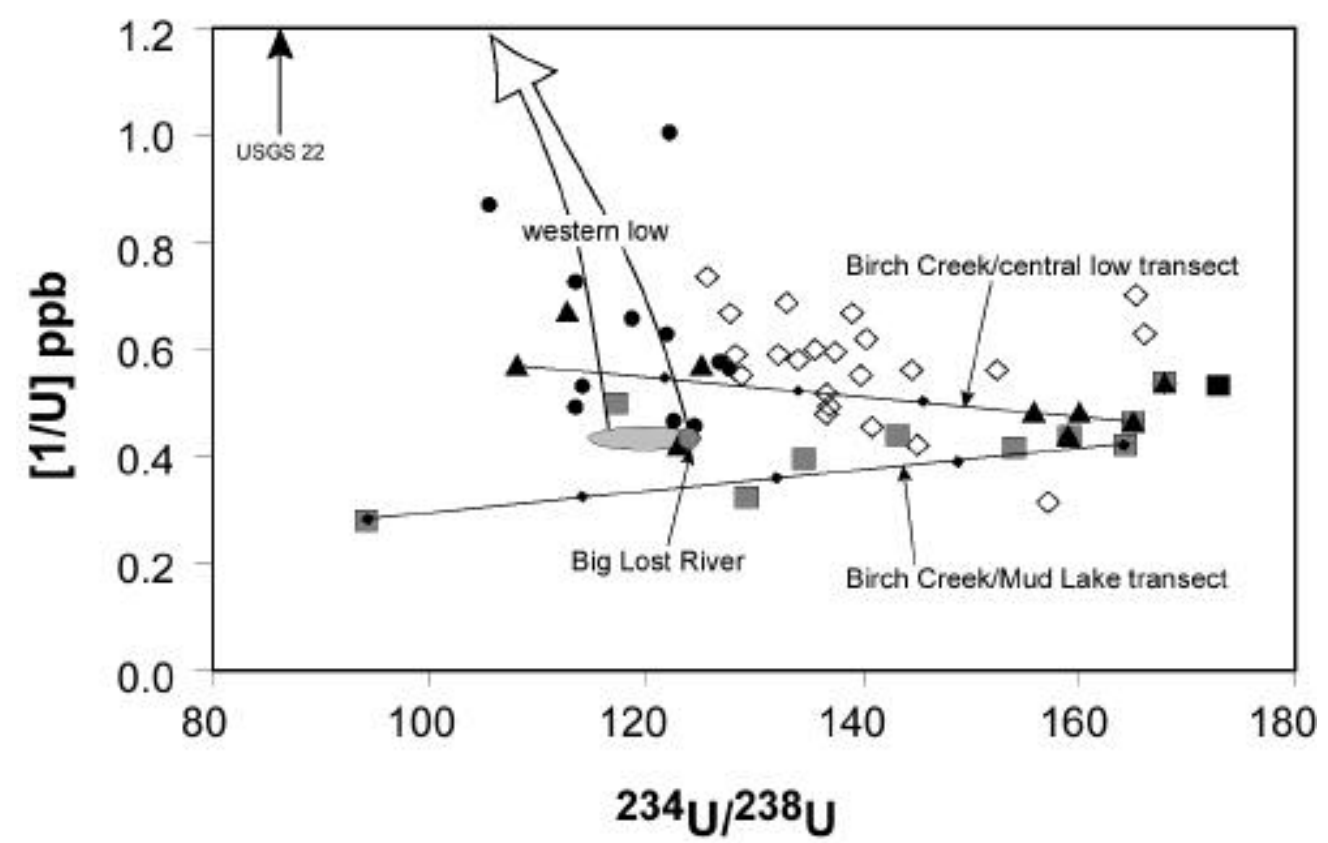

Figure 3. Plot of reciprocal of uranium concentration in parts per billion (ppb) versus ${ }^{234} \mathrm{U} /{ }^{238} \mathrm{U}$ atomic ratios given in ppm. Symbols used are defined in Figure 2. See text for discussion.

Mixing between the groundwater from the local recharge valleys to the north and the groundwater of the regional aquifer to the east is to be expected and is manifested by a northwest to southeast gradient in most solute concentration. Samples along the transect extending from north of TAN to the eastern boundary of the INEEL south of Mud Lake (Fig. 2a) display a crudely linear trend (Fig. 3) suggesting that mixing between these two water masses is an important factor in the observed gradient in ${ }^{234} \mathrm{U}^{238} \mathrm{U}$ ratios. The mixing trend highlights the persistence of Birch Creek groundwater to a distance of about 10km southeast of the TAN site and then rapid dilution by regional aquifer water near the site boundary. Deviations of the data from a perfectly linear array, however, indicate that mixing alone does not explain the trend and water/rock interaction must be invoked to modify the uranium systematics. A pot of ${ }^{234} \mathrm{U} /{ }^{238} \mathrm{U}$ vs. ${ }^{87} \mathrm{Sr} /{ }^{86} \mathrm{Sr}$ shows very good correlation (Fig. 4) that also points to mixing.

Uranium systematics along the transect from the mouth of Birch Creek to the central low also display a linear trend (Fig. 3) suggesting mixing of two water masses. Given the isolated nature of the central low, the only reasonable sources of water in this region could be upwelling of water from greater depths and/or infiltration of surface water derived from the Big Lost River. However, uranium concentrations in these deeper waters are expected to be low due to the typical increase in reducing conditions with depth, a hypothesis that is supported by the low uranium concentrations in the INEL-1 well at 10,300' depths and the Condie Hot Spring (Table 1). Thus, mass balance considerations require large volumes of upwelling water relative to Birch Creek water to produce the trend. No physical (e.g. elevated temperatures) or chemical evidence (e.g. elevated solute concentrations) is observed to support this. It is far more likely that the decrease in ${ }^{234} \mathrm{U} /{ }^{238} \mathrm{U}$ along this trend is produced by mixing of regional groundwater with water that originated as surface water from the Big Lost River, and was subsequently modified by water/rock interaction during infiltration. 


\subsubsection{Water/Rock Interaction}

Uranium isotope-ratio patterns are closely mimicked by ${ }^{87} \mathrm{Sr} /{ }^{86} \mathrm{Sr}$ ratio patterns (Fig. 4).

Groundwater from local recharge areas to the north and west has high ${ }^{87} \mathrm{Sr} /{ }^{86} \mathrm{Sr}(>0.7110)$ reflecting interaction with old (i.e. the age of the original source) clastic material that fills the valleys. The $\mathrm{Sr}$ isotopic ratios of the groundwater decrease away from these areas and approach the isotopic composition of the host basalt $\left({ }^{87} \mathrm{Sr} /{ }^{86} \mathrm{Sr}=0.7070 \pm 0.0003\right.$ [Leeman and Manton, 1971]). Importantly, Sr isotopics are not influenced by processes of alpha recoil or selective leaching, as are U isotopics. The good correlation displayed by these two elements indicates that dissolution of rock with near equilibrium ${ }^{234} U /{ }^{238} U$ ratios dominates over selective leaching and alpha recoil in controlling the uranium isotopic signature of the groundwater.

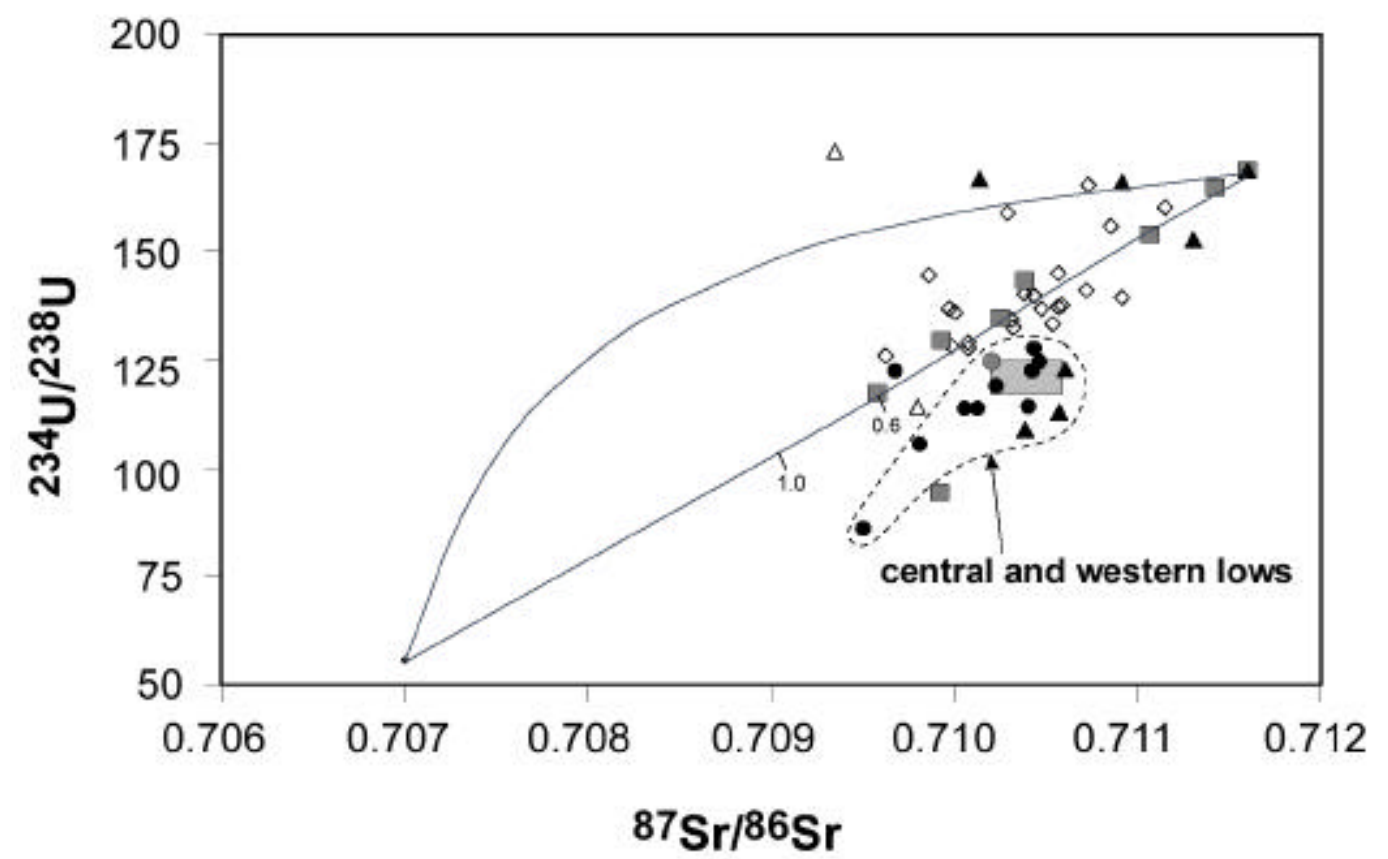

Figure 4. Plot of ${ }^{234} \mathrm{U} /{ }^{238} \mathrm{U}$ versus ${ }^{87} \mathrm{Sr} /{ }^{86} \mathrm{Sr}$. Curves show possible reaction paths. Ticks and number labels show possible reaction progress for grams of reactant per liter of water during the entire reaction history of eth water. Symbols used are defined in Figure 2. See text for discussion.

${ }^{234} \mathrm{U} /{ }^{238} \mathrm{U}$ plotted against ${ }^{87} \mathrm{Sr} /{ }^{86} \mathrm{Sr}$ (Fig. 4) shows a corresponding decrease in both ${ }^{87} \mathrm{Sr} /{ }^{86} \mathrm{Sr}$ and ${ }^{234} \mathrm{U} /{ }^{238} \mathrm{U}$ ratios. The data trend toward the isotopic composition of the basalt, by far the dominant rock type in the aquifer implying that $\mathrm{U}$ and $\mathrm{Sr}$ isotopics were modified through water/basalt interaction. Data from the western and central low-isotope-ratio zones form a distinct field with lower ${ }^{234} \mathrm{U} /{ }^{238} \mathrm{U}$ for corresponding ${ }^{87} \mathrm{Sr} /{ }^{86} \mathrm{Sr}$ than the rest of the data from the fast flow zones and regional aquifer. This is taken to indicate a distinct origin and geochemical evolution of these waters as discussed below.

The data were modeled using a two-end member-mixing model. The endpoints selected for the model are average Snake River Plain basalt and average groundwater of the recharge zones. Changes in the isotopic composition selected for the end members only changes the starting or 
ending points of the model curves. The shape of the mixing line is determined by the $\mathrm{Sr} / \mathrm{U}$ molar ratio of the end members. The upper curve shows the mixing relation using the $\mathrm{Sr} / \mathrm{U}$ molar ratio of average bulk basalt (Knoble et al., 1995) and typical groundwater. This curve as well as others generated using the range of Sr and U concentrations given in Knoble (1995) and reasonable values for these waters do not fit the data. Thus, congruent dissolution of the bulk basalt cannot account for the observed correlation of isotope ratios. The lower hyperbola, which is drawn to fit the data of points excluding the low-isotope-ratio-zones, requires that the $\mathrm{Sr} / \mathrm{U}$ molar ratio of the reactant is lower than that of bulk basalt. Thus, the data are interpreted to suggest that incongruent dissolution of basalt plays an important role in modifying the chemical and isotopic composition of groundwater in the Snake River Plain aquifer.

\subsubsection{The Influence of Surface Water Infiltration}

The Big Lost River drains approximately $1400 \mathrm{mi}^{2}$ to the northwest of the INEEL. The river flows onto the INEEL where it disappears, mostly by infiltration into the aquifer (Bennett, 1990). Since 1965, flow from the Big Lost River has been diverted for flood control into spreading areas in the southwest part of the INEEL (Fig. 2a), where the water rapidly infiltrates into the aquifer. This region of the INEEL also corresponds to the western low-isotope-ratio zone, interpreted as a relatively stagnant region of the aquifer, thus increasing the relative importance of infiltrating waters. Our isotopic data also indicate that water derived from the Big Lost River constitutes a significant volume of the aquifer in the central low.

Uranium and strontium isotopic ratios from samples that define the two low isotope ratio zones reflect infiltration of Big Lost River water. A plot of ${ }^{234} \mathrm{U} /{ }^{238} \mathrm{U}$ vs. ${ }^{87} \mathrm{Sr} /{ }^{86} \mathrm{Sr}$ (Fig. 4) shows that samples that form the low isotope ratio zones define a distinct field with lower ${ }^{234} \mathrm{U} /{ }^{238} \mathrm{U}$ for a corresponding ${ }^{87} \mathrm{Sr} /{ }^{86} \mathrm{Sr}$ than the rest of the aquifer samples. Importantly, the $\mathrm{U}$ and $\mathrm{Sr}$ isotopic composition of the most radiogenic samples is nearly identical to that of the Big Lost River. Samples from the WLZ form an array that trends away from the isotopic composition of the Big Lost River toward lower isotopic ratios, i.e. ratios that are closer to equilibrium with the host rock. A similar, though less well defined trend, is shown by samples from the central low. These data provide excellent evidence that water in the low isotope ratio zones is dominated by infiltrated water from the Big Lost River that has undergone variable degrees of water/rock interaction to lower the isotope ratios as discussed below. The fact that sharp isotopic gradients exist between the western low and the central fast flow zone is good evidence against significant mixing of these water masses and highlights the relative isolation of the western low to regional groundwater flow. Samples from the WLZ, then, must have attained their isotopic signature by water-rock interaction. Importantly, as ${ }^{234} \mathrm{U} /{ }^{238} \mathrm{U}$ decreases in this region, $\mathrm{U}$ concentration, in general, also decreases (Fig. 3). This implies that with increasing water/rock interaction, $U$ is removed from solution. This should have important implications for predicting the fate of uranium waste stored at the RWMC (Fig. 2a).

Samples in the WLZ form coherent fields based on their geographic position relative to the spreading areas. Such patterns likely reflect small-scale flow patterns in the region. A better understanding of these flow patterns could help to predict transport of contaminants from the RWMC (Fig. 2a). 


\subsection{Application of the Short-Lived Uranium-Series Nuclides to Deduce Flow Patterns and Groundwater Evolution}

\subsubsection{Introduction and Model Description}

Performance assessment models for nuclear waste disposal generally invoked laboratory-derived distribution coefficients $(\mathrm{Kd})$ for individual radioelements to simulate the radionuclide migration. Concerns have been raised on the extents to which laboratory data reflect the behavior of natural geochemical systems because of $\mathrm{Kd}$ dependence on $\mathrm{Eh}, \mathrm{pH}$, groundwater chemistry, properties of accessible minerals, kinetics of geochemical processes, and presence of colloids and/or microbial organisms in the system, etc. Natural analog study in geological environments provides an alternative approach to model testing/validation, which has the particular advantages of applying to undisturbed systems and allowing in-situ, long-term migration behavior to be assessed. Naturally occurring uranium and thorium series radionuclides are uniquely suited for this study because several isotopes of the same element continuously enter groundwaters and because the supply rate of many of these radionuclides can be estimated with adequate accuracy (Krishnaswami et al, 1982). In this study we successfully demonstrate that a variety of chemical, geologic and hydrologic processes that control the radionuclide transport can be understood through the decay-series disequilibrium modeling.

$\mathrm{Ku}$ et al $(1992,1998)$ proposed a model that relates the decay-series radionuclide distributions in dissolved, sorbed, and solid pools of a geologic system to in-situ processes of water transport, sorption-desorption, dissolution-precipitation, radioactive ingrowth-decay, and $\alpha$ recoil as follows:

$$
Q+P_{\mathrm{d}}+P_{\mathrm{r}}+R_{f}^{\mathrm{p}} A^{\mathrm{p}}=k_{\mathrm{p}} C+R_{f} A
$$

where $A$ is the nuclide activity in groundwater (dpm $\left.\mathrm{L}^{-1}\right)$, with superscript $p$ referring to its radioactive parent; $k_{\mathrm{p}}$ is the precipitation rate constant $\left(\mathrm{y}^{-1}\right) ; Q, P_{\mathrm{d}}$, and $P_{\mathrm{r}}$ are the rates (atoms L-water-1 $\mathrm{y}^{-1}$ ) of supply by water flow, dissolution, and $\alpha$ recoil, respectively; and $R_{f}$ is the retardation factor, which can be expressed as [1]:

$$
R_{f}=1+K=1+\frac{k_{1}}{k_{2}+\lambda}
$$

where $K$ is a dimensionless distribution coefficient between the sorbed and dissolved pools for the radionuclide that has $k_{1}, k_{2}$ and $\lambda$ as its sorption, desorption, and decay constants $\left(\mathrm{y}^{-1}\right)$, respectively. The model assumed that (1) first-order kinetics govern the processes of sorptiondesorption and dissolution-precipitation of radionuclides; (2) $\alpha$-recoil input from the sorbed and dissolved pools to the solid pool is negligible; and (3) distributions of radionuclides in solid, sorbed, and dissolved pools remain stationary. Implicit in assumption (1) is a linear sorption isotherm for the range of concentrations of the nuclides of interests. For $R_{f}$ to be independent of nuclide concentrations, it also assumed that decay of radionuclides on rock surface (the sorbed pool) releases all their daughter nuclides into the dissolved pool. The validity of these assumptions has been assessed by Ku et al. (1992, 1998) and Murphy (1996). Equation (1) can 
be simplified by setting $Q=0$ for isotopes of Th $(232 \mathrm{Th}, 230 \mathrm{Th}, 228 \mathrm{Th}$, and $234 \mathrm{Th})$ and $\mathrm{Ra}$ (226Ra, 228 Ra, and 224Ra) because of their affinity to the aquifer solids in geologic environments, e.g., at INEEL:

$$
P_{\mathrm{d}}+P_{\mathrm{r}}+R_{f}^{\mathrm{p}} A^{\mathrm{p}}=k_{\mathrm{p}} C+R_{f} A
$$

The dissolution of a nuclide from rocks $\left(P_{\mathrm{d}}\right)$ equals the product of rock dissolution rate $(\omega, \mathrm{g}$ rock L-water-1 $\left.\mathrm{y}^{-1}\right)$ and the nuclide concentration $\left(C \mathrm{r}\right.$, atoms g-rock $\left.{ }^{-1}\right)$ in rocks. The concentrations of a radionuclide in solutions and rocks are inversely related to its decay constant. Therefore, for short-lived radionuclides such as 228Th, 234Th, 228Ra, 224Ra and 222Rn, dissolution and precipitation can be neglected and we have:

$$
P_{\mathrm{r}}+R_{f}^{\mathrm{p}} A^{\mathrm{p}}=R_{f} A
$$

Because $P_{\mathrm{r}} 0$ for $\beta$-decay products, applying eqn (4) to $228 \mathrm{Th}$, one can relate the retardation factors of $228 \mathrm{Th}$ and $228 \mathrm{Ra}$ to their activity ratio $(A \mathrm{Ra} 228 / A \mathrm{Th} 228)$ in groundwater as:

$$
\frac{R_{f, \mathrm{Th} 228}}{R_{f, \mathrm{Ra} 228}}=\frac{A_{\mathrm{Ra} 228}}{A_{\mathrm{Th} 228}}
$$

For uranium isotopes (238U and $234 \mathrm{U}), Q$ is estimated by:

$$
Q=\frac{\left(C^{\mathrm{i}}-C\right)}{\tau_{\mathrm{w}}}
$$

where $C^{\mathrm{i}}$ and $C$ are initial (in recharging waters) and measured concentrations, respectively, and $\tau_{\mathrm{W}}$ is the water transit time in aquifer. Positive values of $Q$ denote net gain due to fluid transport.

Equations (2) through (6) form the basis of our assessment of the effects of sorption-desorption, dissolution-precipitation, and advection-diffusion in radionuclide transport in the groundwater. The $\alpha$-recoil input $\left(P_{\mathrm{r}}\right)$ can be determined from the groundwater $222 \mathrm{Rn}$ activities. The relationships depicted by the above equations allow us to determine retardation factors $\left(R_{f}\right)$ of $\mathrm{U}$, $\mathrm{Th}$ and $\mathrm{Ra}$ from measurements of short-lived $\mathrm{Ra}$ and Th isotopes, as well as the rock dissolution rate $(\omega)$, the precipitation rate constant $\left(k_{\mathrm{p}}\right)$ of $\mathrm{U}$, Th and $\mathrm{Ra}$, and the groundwater transit time $\left(\tau_{\mathrm{W}}\right)$ from measurements of long-lived $\mathrm{U}, \mathrm{Th}$, and Ra isotopes.

\subsubsection{Results and Discussion}

Table I shows the measurements of isotopes of $\mathrm{U}(238 \mathrm{U}, 234 \mathrm{U})$, Th $(232 \mathrm{Th}, 230 \mathrm{Th}, 228 \mathrm{Th}$, 234 Th), Ra (226Ra, 228Ra, 224Ra), and Rn (222Rn) in groundwaters collected from INEEL (Figs. 1 and 2). The results show a tremendous range of activities: from $10^{4}-10^{6} \mathrm{dpm} \mathrm{m}^{-3}$ for $222 \mathrm{Rn}$, to $10^{3} \mathrm{dpm} \mathrm{m}-3$ for $238 \mathrm{U}$ and $234 \mathrm{U}$, to $10-10^{2} \mathrm{dpm} \mathrm{m}^{-3}$ for $226 \mathrm{Ra}, 228 \mathrm{Ra}, 224 \mathrm{Ra}$, and $234 \mathrm{Th}$, and to less than $1 \mathrm{dpm} \mathrm{m}^{-3}$ for $232 \mathrm{Th}, 230 \mathrm{Th}$, and $228 \mathrm{Th}$. Radioactive disequilibria 
among the decay-series nuclides occurred as a result of water-rock interaction (see above). Applying the observed radioactive disequilibria to the above-stated model, we made estimates on rates of $\alpha$ recoil, sorption-desorption, and dissolution-precipitation; in-situ retardation factors of isotopes of $\mathrm{U}$, Th and Ra; and water transit time in the aquifer. The major modeling results are summarized in Table II.

Table I. Measurements of decay-series isotope activities and activity ratios in groundwater at INEEL, Idaho*

\begin{tabular}{|c|c|c|c|c|c|c|c|c|c|c|c|}
\hline Well No. & $\begin{array}{c}238 \mathrm{U} \\
\mathrm{dpm} / \mathrm{L}\end{array}$ & $\begin{array}{c}232 \mathrm{Th} \\
\mathrm{dpm} / \mathrm{m}^{3}\end{array}$ & $\begin{array}{c}226 \mathrm{Ra} \\
\mathrm{dpm} / \mathrm{m}^{3}\end{array}$ & $\begin{array}{l}222 \mathrm{Rn} \\
\mathrm{dpm} / \mathrm{L}\end{array}$ & $\begin{array}{l}{ }^{234} \underline{\mathrm{U}} \\
238 \underline{\mathrm{U}}\end{array}$ & ${ }^{2334} \underline{\mathrm{Th}}$ & ${ }^{230} \underline{\mathrm{Th}}$ & $\begin{array}{l}{ }^{228} \underline{\mathrm{Th}} \\
232 \mathrm{Th}\end{array}$ & ${ }^{228} \frac{\mathrm{Th}}{\mathrm{Ra}}$ & ${ }_{228}^{226 \mathrm{Ra}}$ & ${ }_{224}^{22} \underline{\mathrm{Ra}}$ \\
\hline USGS-124 & 1.200 & 0.492 & 47.2 & (170) & 2.54 & 0.056 & 1.18 & 4.6 & 0.068 & 1.84 & 1.01 \\
\hline USGS-86 & 0.765 & 2.761 & 18.8 & (860) & 2.00 & 0.036 & 0.95 & 1.2 & 0.068 & 2.66 & 1.47 \\
\hline USGS-101 & 0.987 & 0.055 & 10.9 & (50) & 2.20 & 0.043 & 1.23 & 3.9 & 0.016 & 1.21 & 1.03 \\
\hline USGS-103 & 1.099 & 0.110 & 5.1 & (117) & 2.12 & 0.038 & 1.18 & 3.4 & 0.045 & 1.65 & 1.20 \\
\hline USGS-108 & 1.311 & 0.129 & 4.3 & (47) & 2.12 & 0.019 & 1.25 & 1.7 & 0.044 & 1.19 & 1.33 \\
\hline USGS-19 & 1.173 & 0.045 & 1.5 & (346) & 2.92 & 0.017 & 1.00 & 2.1 & 0.028 & 2.20 & 2.18 \\
\hline USGS-12 & 1.763 & 0.070 & 14.0 & (632) & 2.61 & 0.028 & 1.46 & 5.5 & 0.011 & 2.51 & 1.23 \\
\hline ANP-6 & 1.630 & 0.035 & 7.4 & (1455) & 2.95 & 0.024 & 1.18 & 14.3 & 0.023 & 2.93 & 4.18 \\
\hline USGS-17 & 1.288 & 0.686 & 17.4 & (209) & 1.89 & 0.015 & 1.01 & 1.5 & 0.031 & 1.94 & 1.14 \\
\hline Site 14 & 1.545 & 0.053 & 14.9 & (112) & 2.51 & 0.023 & 1.27 & 7.7 & 0.017 & 1.62 & 1.54 \\
\hline USGS-18 & 1.540 & 0.054 & 10.4 & (361) & 2.57 & 0.031 & 1.27 & 7.6 & 0.018 & 2.22 & 1.52 \\
\hline USGS-6 & 1.306 & 0.266 & 14.5 & (114) & 2.23 & 0.029 & 1.06 & 3.8 & 0.042 & 1.63 & 1.09 \\
\hline USGS-110 & 1.516 & 0.037 & 14.3 & 16 & 2.42 & 0.021 & 1.59 & 5.6 & 0.021 & 0.70 & 1.26 \\
\hline USGS-2 & 1.356 & 0.033 & 15.3 & 37 & 2.23 & 0.017 & 1.89 & 3.3 & 0.006 & 1.28 & 1.34 \\
\hline USGS-107 & 1.640 & 0.024 & 8.5 & 84 & 2.37 & 0.014 & 1.50 & 4. & 0.008 & 1.59 & 1.14 \\
\hline USGS-83 & 1.019 & 0.035 & 18.4 & 565 & 2.12 & 0.023 & 1.32 & 7.7 & 0.006 & 2.38 & 1.16 \\
\hline USGS-22 & 0.323 & 1.754 & 19.3 & 293 & 1.60 & 0.071 & 0.99 & 2.2 & 0.084 & 2.37 & 1.18 \\
\hline USGS-1 & 1.279 & 0.036 & 11.6 & 22 & 2.37 & 0.017 & 1.53 & 6.7 & 0.019 & 1.08 & 1.31 \\
\hline USGS-9 & 1.175 & 0.090 & 11.9 & 85 & 2.14 & 0.019 & 1.23 & 3.1 & 0.023 & 1.02 & 1.28 \\
\hline USGS-109 & 1.293 & 0.051 & 6.6 & 73 & 2.07 & 0.029 & 1.45 & 4.4 & 0.020 & 1.68 & 1.33 \\
\hline USGS-27 & 2.310 & 0.628 & 15.6 & 465 & 2.40 & 0.010 & 0.98 & 1.5 & 0.031 & 1.94 & 1.49 \\
\hline USGS-31 & 1.695 & 0.167 & 13.9 & 314 & 2.43 & 0.010 & 0.96 & 5.2 & 0.031 & 2.00 & 1.62 \\
\hline USGS-26 & 1.780 & 0.050 & 8.4 & 42 & 2.75 & 0.007 & 1.00 & 5.9 & 0.035 & 1.01 & 1.55 \\
\hline
\end{tabular}

* Except for $238 \mathrm{U}$ which was measured by thermal ionization mass spectrometry, all isotopes were measured by decay counting techniques [5]. The analytical errors $(1-\sigma)$ derived from counting statistics were $<0.5 \%$ for ${ }^{238 \mathrm{U}},<5 \%$ for ${ }^{234} \mathrm{U},{ }^{234} \mathrm{Th},{ }^{228} \mathrm{Th},{ }^{226} \mathrm{Ra},{ }^{228} \mathrm{Ra},{ }^{224} \mathrm{Ra}$ and ${ }^{222} \mathrm{Rn}$, and about $3-10 \%$ for ${ }^{230} \mathrm{Th}$ and ${ }^{232} \mathrm{Th}$. The data in parentheses are interpolated from the observed relationship between ${ }^{228} \mathrm{Ra} / 226 \mathrm{Ra}$ and ${ }^{222} \mathrm{Rn}[5]$.

\section{Alpha-Recoil Input}

The model-derived $\alpha$-recoil rates exhibit great regional variations, varying from $\sim 2.0$ atoms $\mathrm{L}^{-1}$ $\min ^{-1}$ at USGS-124, -101, and -110 from southern parts of INEEL to $\sim 1300$ atoms $\mathrm{L}^{-1} \mathrm{~min}^{-1}$ at ANP-6 to the north. Given an $\alpha$-recoil range of $\sim 0.05 \mu \mathrm{m}$, rock density of $\sim 2.8 \mathrm{~g} \mathrm{~cm}^{-3}$ and $238 \mathrm{U}$ activity of $0.3 \mathrm{dpm} \mathrm{g-1} \mathrm{in} \mathrm{basalt} \mathrm{at} \mathrm{INEEL[5],} \mathrm{these} \mathrm{rates} \mathrm{can} \mathrm{be} \mathrm{translated} \mathrm{to} \mathrm{an} \mathrm{effective} \mathrm{surface}$ area $(S)$ of the aquifer rocks in the range $(2-1300) \infty 10^{6} \mathrm{~cm}^{2} \mathrm{~L}^{-1}$, or a fracture width of $\sim 0.02-10$ 
$\mu \mathrm{m}$ for a planar structure or a pore diameter of $\sim 0.04-20 \mu \mathrm{m}$ for a tubular configuration. Relatively large fractures occur in the southern part of INEEL. It is noted that the estimated fracture width can be smaller than the $\alpha$-recoil range. This may imply that the $222 \mathrm{Rn}$ released by $\alpha$ recoil can readily dissolve in interstitial waters within microfractures and rapidly travel to larger fractures and sampling wells.

The model-derived $\alpha$-recoil rates (Table II) are significantly lower than the $222 \mathrm{Rn}$ activities in groundwater (Table I), suggesting that the in-situ production from decay of 226Ra in the dissolved and sorbed pools must contribute an important source of $222 \mathrm{Rn}$ in groundwater. This is particular true for the groundwaters collected from the southern parts of INEEL, where the

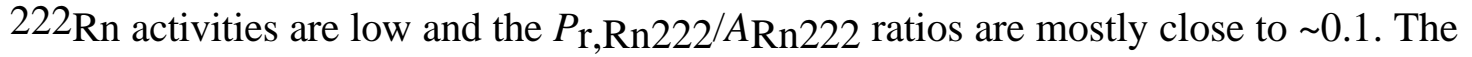
$P_{\mathrm{r}, \mathrm{Rn} 222} / A_{\mathrm{Rn} 222}$ ratios are mostly found high in the recharging areas and decrease along the major flow paths. The $\mathrm{U}$ and $\mathrm{Th}$ concentrations in rocks are generally constant throughout the study area and typical of those in basalt (Knobel et al, 1995). Therefore, fracture size and density, not chemical composition, of the aquifer rock exert the main controls on the supply rates of $222 \mathrm{Rn}$ by $\alpha$-recoil.

\section{Retardation Factors of $R a$, Th and $U$}

Ra isotopes: In spite of their different half-lives, the Ra isotopes (226 Ra, 228Ra and 224Ra) have similar $R f$ values, as seen from the following equation given by the model:

$$
P_{\mathrm{r}, \mathrm{Ra} 224}+R_{f, \mathrm{Ra} 228} A_{\mathrm{Ra} 228}=R_{f, \mathrm{Ra} 224} A_{\mathrm{Ra} 224}
$$

For most of samples, ARa224 is only slightly higher than ARa228 (Table I). Equation (2)

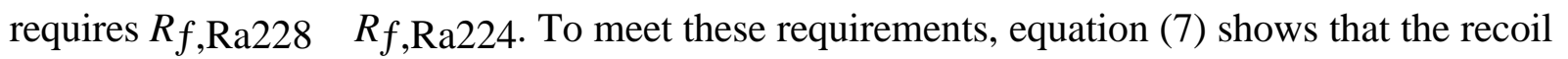
input of $224 \mathrm{Ra}$ from rocks (mainly basalt) must be small and $R_{f}$, Ra228 $R_{f}$, Ra224, i.e., the desorption rate constant $\left(k_{2}\right)$ of Ra must be much greater than the decay constant of ${ }^{224} \mathrm{Ra}(=$ 0.19 day$\left.^{-1}\right)$. Thus we have: $R_{f, \operatorname{Ra} 224}=R_{f, \operatorname{Ra} 228}=R_{f, \mathrm{Ra} 226}=R_{f, \mathrm{Ra}}$. It is also inferred that the activity of $224 \mathrm{Ra}$ in any groundwater should not be smaller than that of $228 \mathrm{Ra}$. However, because of the short half life of ${ }^{224} \mathrm{Ra}$, aging of water in well bores (e.g., the wells are not completely purged before sampling) or in large fractures may cause the $224 \mathrm{Ra} / 228 \mathrm{Ra}$ ratio to become $<1$.

Table II. Model-derived $\alpha$-recoil rate $\left(P_{\mathrm{r}}\right.$, atoms $\left.\mathrm{L}^{-1} \mathrm{~min}^{-1}\right)$ of $222 \mathrm{Rn}$, ratardation factors $\left(R_{f}\right)$ and precipitation rate constants $\left(k_{\mathrm{p}}, \mathrm{y}^{-1}\right)$ of $\mathrm{Ra}, \mathrm{Th}$, and $\mathrm{U}$, rock dissolution rate $\left(\omega, \mathrm{mg} \mathrm{L}^{-1} \mathrm{y}^{-1}\right)$, and water transit time $\left(\tau_{\mathrm{w}}, \mathrm{y}\right)^{*}$

\begin{tabular}{|c|c|c|c|c|c|c|c|c|c|c|c|}
\hline Well No. & $P_{\mathrm{r}} \infty 10$ & $\begin{array}{c}2 R_{f} \infty 10^{-} \\
4 \\
(\mathrm{Ra})\end{array}$ & $\begin{array}{c}R_{f} \infty 10^{-} \\
6 \\
(232 \mathrm{Th})\end{array}$ & $\begin{array}{c}R_{f} \infty 10^{-} \\
6 \\
(228 \mathrm{Th})\end{array}$ & $\begin{array}{c}R_{f} \infty 10^{-} \\
6 \\
(224 \mathrm{Th})\end{array}$ & $\begin{array}{c}R_{f} \infty 10- \\
3 \\
(\mathrm{U})\end{array}$ & $\begin{array}{c}k_{\mathrm{p}} \infty 10^{-3} 3 \\
(\mathrm{Th})\end{array}$ & $\begin{array}{c}k_{\mathrm{p}} \infty 10^{-1} \\
(\mathrm{Ra})\end{array}$ & $\begin{array}{c}k_{\mathrm{p}} \infty 10 \\
(\mathrm{U})\end{array}$ & $\omega$ & $\tau_{\mathrm{w}}$ \\
\hline USGS-124 & 0.02 & 0.36 & 0.62 & 0.14 & 0.006 & 0.34 & 0.04 & 0.22 & 0.29 & 71 & 39.8 \\
\hline USGS-86 & 4.56 & 2.14 & $* *$ & 0.32 & 0.051 & 1.87 & 0.08 & 3.11 & 3.52 & 736 & 16.2 \\
\hline USGS-101 & 0.02 & 0.44 & 1.03 & 0.27 & 0.013 & 0.53 & 0.55 & 0.34 & 0.39 & 98 & 75.3 \\
\hline USGS-103 & 0.27 & 1.76 & 1.07 & 0.39 & 0.021 & 0.76 & 0.49 & 1.61 & 0.56 & 176 & 57.5 \\
\hline
\end{tabular}




\begin{tabular}{lrrrrrrrrrrr} 
USGS-108 & 0.13 & 0.81 & 0.21 & 0.19 & 0.041 & 0.76 & 0.42 & 1.27 & 0.43 & 176 & 69.4 \\
USGS-19 & 2.43 & 6.86 & $* *$ & 2.43 & 0.051 & 0.67 & 4.95 & 20.57 & 14.48 & 718 & 0.4 \\
USGS-12 & 2.16 & 2.97 & 11.50 & 2.73 & 0.123 & 3.27 & 3.32 & 4.51 & 1.20 & 750 & 15.6 \\
ANP-6 & 13.02 & 2.07 & $* *$ & 0.89 & 0.051 & 0.42 & 3.00 & 8.22 & 2.33 & 344 & 0.6 \\
USGS-17 & 0.41 & 0.96 & 0.41 & 0.31 & 0.040 & 0.56 & 0.14 & 0.88 & 0.72 & 310 & 76.9 \\
Site 14 & 0.50 & 0.42 & 0.87 & 0.25 & 0.012 & 0.23 & 0.42 & 0.27 & 0.16 & 73 & 64.4 \\
USGS-18 & 1.85 & 1.69 & 3.41 & 0.94 & 0.044 & 1.24 & 2.22 & 2.06 & 0.88 & 388 & 9.4 \\
USGS-6 & 0.13 & 0.70 & 0.57 & 0.16 & 0.008 & 0.22 & 0.11 & 0.40 & 0.24 & 95 & 92.9 \\
USGS-110 & 0.02 & 2.06 & 5.47 & 0.99 & 0.041 & 0.87 & 1.02 & 0.33 & 0.26 & 123 & 48.8 \\
USGS-2 & 0.10 & 1.62 & 9.23 & 2.92 & 0.146 & 2.40 & 1.88 & 1.33 & 0.49 & 200 & 41.6 \\
USGS-107 & 0.14 & 3.36 & 18.27 & 4.47 & 0.202 & 2.84 & 6.64 & 3.65 & 0.92 & 514 & 21.1 \\
USGS-83 & 1.47 & 1.38 & 12.78 & 2.27 & 0.094 & 2.01 & 2.48 & 1.55 & 0.99 & 278 & 33.3 \\
USGS-22 & 0.83 & 1.28 & $* *$ & 0.15 & 0.051 & 3.40 & 0.08 & 1.38 & 4.63 & 456 & 66.8 \\
USGS-1 & 0.05 & 2.27 & 7.73 & 1.17 & 0.047 & 0.80 & 0.82 & 0.85 & 0.28 & 95 & 53.8 \\
USGS-9 & 0.18 & 2.29 & 2.87 & 1.00 & 0.052 & 0.97 & 0.67 & 0.68 & 0.57 & 196 & 50.7 \\
USGS-109 & 0.24 & 3.45 & 7.03 & 1.73 & 0.078 & 2.29 & 1.87 & 3.34 & 0.75 & 305 & 43.4 \\
USGS-27 & 2.15 & 1.19 & $* *$ & 0.38 & 0.051 & 0.40 & 0.40 & 0.22 & $(-4.0)$ & 812 & $(0.4)$ \\
USGS-31 & 1.67 & 1.16 & 0.84 & 0.38 & 0.023 & 0.14 & 0.53 & 1.01 & 0.48 & 285 & 45.1 \\
USGS-26 & 0.14 & 2.71 & 4.30 & 0.78 & 0.033 & 0.24 & 1.75 & 0.94 & 0.45 & 282 & 29.6 \\
\hline
\end{tabular}

* The model input also included: the activities of 0.28 and $0.31 \mathrm{dpm} / \mathrm{g}$ for $238 \mathrm{U}$ and $232 \mathrm{Th}$ in the basalt, and of 1.8 and $5.4 \mathrm{dpm} / \mathrm{L}$ for $238 \mathrm{U}$ and $234 \mathrm{U}$ in the recharging waters, respectively. The $\alpha$ recoil input for the $\mathrm{Th}$ series nuclides equals that of $222 \mathrm{Rn}$ multiplying by 0.9 . The parenthesized values at USGS-27 is anomalous due to influence of agriculture in the vicinity of the well on the groundwater $U$ concentration [5]. Major contributions of the uncertainties in the estimates are from the estimate of the $\alpha$-recoil input of the nuclides to the groundwater, which may vary by up to a factor of 2 [1].

** Values are either negative or smaller than those of $228 \mathrm{Th}$. In these cases, same retardation factors were assumed for $232 \mathrm{Th}$ and $228 \mathrm{Th}$ and average $k_{1}$ and $k_{2}$ values, $1.08 \mathrm{~min}^{-1}$ and $0.58 \mathrm{y}^{-1}$, respectively, were used to calculate $R_{f, \mathrm{Th} 234}$.

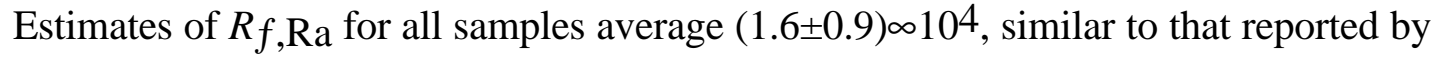
Krishnaswami et al. (1982) for a number of gravel aquifers in Connecticut. Although the two aquifers have different rock types, they are all nearly saturated by dissolved oxygen, and contain relatively low dissolved solids. For hypersaline or more reducing waters, Ra generally has higher mobility (Zikin et al, 1987). It appears that the groundwater chemistry, not the mineralogy of the aquifer rocks, exerts main control on the retardation of Ra isotopes. Our estimates may reflect the typical $R_{f}$, Ra values for the oxygenated, low-salinity groundwaters.

We have shown that the minimum desorption rate constant of $\mathrm{Ra}$ is $0.19 \mathrm{~d}-1$. Therefore, from eqn. (2), the sorption rate constant $\left(k_{1}\right)$ of $\mathrm{Ra}$ is estimated to has a minimum value of $2.1 \pm 1.2$ $\min ^{-1}$, i.e., the sorption occurs on time scales of less than one minute, much faster than their transport by groundwater flow.

Th isotopes: The retardation factors of $228 \mathrm{Th}\left(R_{f} \mathrm{Th} 228\right)$ were estimated using eqn. (5) to range mostly from 105 to 106 , about two orders higher than that of Ra isotopes. $R f T h 228$ exhibits large spatial variations. Low $R_{f} \mathrm{Th} 228$ values occur mainly in wells south of the three mountain 
ranges where we found high $230 \mathrm{Th}$ and $232 \mathrm{Th}$ concentrations due possibly to colloidal association. The low $R_{f}$ Th228 values could also reflect such an association. The retardation factors of Th isotopes were estimated to be isotope-dependent: $232 \mathrm{Th} \quad 230 \mathrm{Th}>228 \mathrm{Th}>234 \mathrm{Th}$ (Table II). That $R_{f} \mathrm{Th} 232>R_{f} \mathrm{Th} 228$ for most of samples suggests that the desorption rate constant of Th must be comparable to or smaller than the decay constant of $228 \mathrm{Th}\left(0.363 \mathrm{y}^{-1}\right)$. From eqn. (2), we estimated the sorption and desorption rate constants ( $k_{1}$ and $\left.k_{2}\right)$ of Th to range from 0.12 to $4.1 \mathrm{~min}^{-1}$ and 0.1 to $2.5 \mathrm{y}^{-1}$. Whereas the sorption rates of Th and $\mathrm{Ra}$ are comparable, the desorption of $\mathrm{Th}$ is about two orders slower than that of Ra.

$U$ isotopes: The $R_{f}$ values of $238 \mathrm{U}$ and $234 \mathrm{U}$ are mostly in the range of $10^{2}-10^{3}$, much smaller than those for Ra and Th isotopes. However, even in this oxygenated, bicarbonate-rich groundwater of INEEL, $\mathrm{U}$ is still moderately retarded by the aquifer solids.

\section{Dissolution and Precipitation}

Dissolution and precipitation exhibit large spatial variations (Table II), with high rates occurring in recharge areas of the Birch Creek and Little Lost River drainages. There, the groundwater apparently is "aggressive" enough to dissolve aquifer rocks at a rate up to $800 \mathrm{mg} \mathrm{L}^{-1} \mathrm{y}^{-1}$, much higher than rates of $<100 \mathrm{mg} \mathrm{L}^{-1} \mathrm{y}^{-1}$ in southeastern INEEL where the groundwater is older. If the dissolution rate is assumed to be constant with time, it would take about less than one million years for the aquifer rocks to be completely weathered. However, since dissolution occurs mainly in the fractured rocks, fresh basalts of one million years old may still exist if they are not fractured.

Precipitation occurs on the time scales of days for Th, years for Ra, and $10^{2}$ years for $U$ and shows large regional variations. High $k_{\mathrm{p}}$ values are generally found in the areas of high dissolution rates, e.g., in the recharging regions north of INEEL. The high dissolution and precipitation rates reflect rapid rock weathering in these areas and are likely to be associated with the presence of abundant microfractures in aquifer rocks as suggested by the groundwater ${ }^{222} \mathrm{Rn}$ data discussed earlier.

The above estimates point to that, for short-lived Th $\left({ }^{234} \mathrm{Th}\right.$ and $\left.{ }^{228} \mathrm{Th}\right)$ and $\mathrm{Ra}\left({ }^{228} \mathrm{Ra}\right.$ and ${ }^{224} \mathrm{Ra}$ ) isotopes, the dissolution and precipitation rates are orders-of-magnitude lower than the rates of supply by in-situ production from their sorbed and dissolved parents and/or by $\alpha$-recoil injection from the solid pool. This justifies the neglect of the dissolution and precipitation for short-lived Th and Ra isotopes in our model assumptions. However, for long-lived U ( ${ }^{234} \mathrm{U}$ and $\left.{ }^{238} \mathrm{U}\right)$, Th $\left({ }^{230} \mathrm{Th}\right.$ and $\left.{ }^{232} \mathrm{Th}\right)$, and $\mathrm{Ra}\left({ }^{226} \mathrm{Ra}\right)$ isotopes, dissolution and precipitation have rates comparable to, or greater than, the in-situ production and/or $\alpha$-recoil supply. These processes must all be taken into account in the model simulations. 


\section{Groundwater Transit Time}

The estimated groundwater transit time $\left(\tau_{\mathrm{W}}\right)$ ranges from $<10 \mathrm{y}$ in the recharge regions to $>90 \mathrm{y}$ in central INEEL, with the oldest groundwaters occurring at the central and southeast parts. For the entire Snake River Plain Aquifer, it has been estimated at 200-250 y (Wood and Low, 1986). By dividing the aquifer into several compartments, Ackerman (1995) showed the travel time of regional flows for the Mud Lake compartment, which covers the INEEL area, to be less than 100 y.

The spatial variation of $\tau_{\mathrm{W}}$ serves to highlight the preferential flow paths in the aquifer. As seen from Fig. 2b, there are two major groundwater pathways. Recharged water migrates from the vicinity of Birch Creek and Little Lost River via two preferential paths southward into the major aquifer. Stagnated water exists in the central and western low-isotope-ratio zones. A relative young water occurs at USGS-86 in the southwestern corner of INEEL and may originate from the Big Lost River drainage.

\subsection{Conclusions}

This study demonstrates the utility of natural-occurring uranium-series nuclides to characterize flow patterns and rates of contaminant migration in a fractured rock aquifer. We successfully delineated detailed groundwater flow pathways, assessed mixing volumes and water/rock interaction, and predicted solute migration rates at INEEL. Two zones of preferential flow were identified that are interpreted to represent pathways along which groundwater from the Birch Creek and Little Lost Rivers is channeled. Conversely, two zones of relatively stagnant groundwater were identified. These areas are physically isolated from the more rapid regional flow by low permeability zones.

Modeling $U$ and Th series disequilibria in the groundwater at INEEL placed constraints on the following in-situ parameters: (1) time scales of sorption (minutes for $\mathrm{Ra}$ and $\mathrm{Th}$ ), desorption (days for Ra and years for Th), and precipitation (days for Th, years for Ra, and centuries for $\mathrm{U}$ );

(2) retardation factors due to sorption ( $>10^{6}$ for ${ }^{232} \mathrm{Th}, \sim 10^{4}$ for ${ }^{226} \mathrm{Ra}$, and $\sim 10^{3}$ for $238 \mathrm{U}$ ); (3) dissolution rates of rocks ( $\sim 70$ to $800 \mathrm{mg} / \mathrm{L} / \mathrm{y})$; and (4) groundwater transit time (<10 to $\sim 90$ years). Groundwater chemistry and the size and density of microfracture in rocks exert an important control on the retardation factors, precipitation and dissolution rates, and $\alpha$-recoil rates of the radionuclides in groundwater.

Studies of radionuclide transport in geologic systems based on naturally occurring decay-series disequilibria, such as the multiple-tracer approach of the present study, have the advantage of obtaining in-situ hydrologic information integrated over a range of timescales. This study provides a clearer picture of the physical and chemical hydrology of the Snake River Plain aquifer beneath INEEL than was previously available. This information is proving to be extremely valuable to environmental management projects at the INEEL. Methods developed as part of this study have been applied at Rocky Flats and could be applied at other sites to 
characterize the physical and chemical hydrology. Such information is invaluable, particularly at sites where expensive groundwater remediation is being undertaken or considered.

\section{Relevance, Impact, and Technology Transfer:}

\section{A. How does this new scientific knowledge focus on critical DOE environmental management problems?}

This research falls under one of the five focused topical areas of the ER/EM Collaborative Research Program (Topic 1 of the ER/EM Collaborative Research Solicitation: September 1995). It is directed toward a quantitative assessment of the rates of water-rock-radionuclide interactions, the preferential groundwater flow paths, and the transport of radionuclides in fracture-rock systems using a natural analog approach. It provides an improved characterization of preferential flows and contaminant transport in fractured rocks - information that pertains to risk assessment and remediation action. This study was carried out at INEEL and has generated two related projects funded through their environmental management programs. These projects employ similar investigations using uranium isotopes but are aimed at providing a more detailed picture of flow and contaminant migration near waste storage sites (RWMC). Some aspects of this research have also been applied to Rocky Flats where the characterization of the extent of contaminant plumes has been used for accurate planning (cost and schedule), risk evaluation, and remediation decisions.

B. How will the new scientific knowledge that is generated by this project improve technologies and cleanup approaches to significantly reduce future costs, schedules, and risks and meet DOE compliance requirements?

By better understanding flow patterns and contaminant migration rates we can guard high risk areas, and neglect low risk areas. Direct identification of extent of contamination decreases costs significantly relative to baseline assumptions of the potential extent based on associated mobile species. For example, at Rocky Flats the solar ponds plume containing uranium and nitrate was known to exist within a high background of natural uranium. Before this new scientific knowledge and techniques were demonstrated, planning for remediation had used the nitrate cocontaminant as the basis for both nitrate and uranium treatment scope, costs, schedules and risks. Demonstration analyses on Rocky Flats water samples showed that the uranium plume is very much smaller than the nitrate plume used for planning baselines, with significantly decreased risks allowing implementation of a treatment system focused on nitrate at lower costs.

C. To what extent does the new scientific knowledge bridge the gap between broad fundamental research that has wide-ranging applications and the timeliness to meet needs-driven applied technology development?

This project took basic research and capabilities developed under the US DOE BES/Geoscience Program and focused on the developments necessary to demonstrate immediate applicability to regional scale characterization of subsurface transport (INEEL). The new knowledge serves to expand our understanding of in situ migration of nuclear waste that has previously been deduced largely by extrapolation from small-scale laboratory experiments over limited time scales. 
D. What is the project's impact on individuals, laboratories, departments, and institutions? Will results be used? If so, how will they be used, by whom, and when?

Results of this project have impacted many ongoing environmental investigations at the INEEL. Our data are being incorporated into the regional flow and transport model, which will be the ultimate assessment of risk from saturated-zone contaminants. Our interpretations are being used by the environmental remediation program in many of their investigative projects. The INEEL groundwater monitoring committee is evaluating our data and interpretations and their implications for saturated-zone flow and transport. Ongoing investigations and WAG-3 (RWMC) are also utilizing information provided by our project. Our project results led to funding of two additional projects at the INEEL that are geared toward a more detailed investigation of flow and contaminant transport around WAG-3.

The project results from INEEL lead to RFETS funding (through the Environmental Remediation department run by Lane Butler) for demonstration on a small number of groundwater samples to evaluate the ability to differentiate natural background from contamination uranium. These results were used in the final definition and permitting of interception and treatment of the Solar Ponds

E. Are larger scale trials warranted? What difference has the project made? Now that the project is complete, what new capacity, equipment or expertise has been developed?

Additional studies at both larger and smaller scale are warranted at INEEL. Larger scale studies would provide information of flow and transport to regions off site and, in particular, down gradient, where water that flowed through INEEL is used extensively for irrigation and drinking. Smaller scale studies are needed to provide a detailed picture of flow and transport around waste disposal sites. Such studies should be extended to include the vadose zone. Studies similar to this one would also be quite useful at most DOE sites, or any site where contamination has, or may impact the saturated zone.

The project was the first to use the full suite of uranium-series nuclides. We successfully developed methods to measure the extremely small quantities of most of the nuclides in groundwater. Many lessons were learned in the process. As a result, methods employed in this study are now ready to employ in future investigations.

Regulators at the Colorado Department of Public Health and Environment were so interested and pleased with the results of the demonstration that they have worked with Kaiser-Hill as the RFETS contractor to redirect funds in FY00 for a deployment project with a more comprehensive suite of samples. The EMSP project provided the opportunity and funding to focus a research capability on a DOE problem, to generate a focused set of results

\section{F. How have the scientific capabilities of collaborating scientists been improved?}

Our study introduced many collaborating scientists at INEEL to the utility of uranium-series nuclides for saturated-zone flow and transport studies. 


\section{G. How has this research advanced our understanding in the area?}

The work has detailed the complexities of flow and transport in a fractured rock aquifer at an important DOE site.

$\mathrm{H}$. What additional scientific or other hurdles must be overcome before the results of this project can be successfully applied to DOE Environmental Management problems?

The results of the work provide better science-based risk assessment. However, such assessments are based on models, which, by definition, represent simplifications of an extremely complex hydrologic system. These models should continue to be evaluated for accuracy. For example, our model treatment of the interfacial processes of dissolution-precipitation and adsorptiondesorption has left room for improvement, in the sense that bulk averages rather than individual mineral surfaces are considered. The role of colloidal transport also awaits evaluation, as do the influences of water chemistry and rock mineralogy.

The results can currently be applied to DOE environmental management problems. The results of this project have been demonstrated and will be deployed. Other hurdles that must be are development of broader visibility for this capability in the environmental restoration projects around the DOE complex.

I. Have any other government agencies or private enterprises expressed interest in the project? Please provide contact information.

Contact information for persons who have expressed interest in the project:

Dr. Bret W. Leslie

U. S. Nuclear Regulatory Commission MS T-7C6

Washington, DC 20555-0001

phone: (301) 415-6652

email: bwl@nrc.gov

Dr. William M. Murphy

Center for Nuclear Waste Regulatory

Analyses

Southwest Research Institute

6220 Culebra Road

San Antonio, Texas 78238-5166

phone: (210) 522-5263

email: wmurphy@swri.org
Dr. John F. McCarthy

Environmental Sciences Division

Oak Ridge National Laboratory

P.O. Box 2008, Bethel Valley Road

Oak Ridge TN 37831-6036

phone: (423) 576-6606

email: jjj@ornl.gov

Dr. Boris Faybishenko

Earth Sciences Division

Lawrence Berkeley National Laboratory

Berkeley, CA 94720

phone: (510)486-4852

email: bfayb@lbl.gov 
Swen Magnuson

INEEL

2251 North Blvd

Idaho Falls, ID 83415-2107

Christine Dayton

phone: (208) 526-8618

Environmental Management and

Compliance

Kaiser-Hill, LLC.

Rocky Flats Environmental Technology Site

Lane Butler

P.O. Box 464

Environmental Management and

Golden, CO 80402

Compliance

phone: (303) 966-9887

Kaiser-Hill, LLC.

Rocky Flats Environmental Technology Site

P.O. Box 464

Golden, CO 80402

phone: (303) 966-5245

email: bulter.lane@rfets.gov

email: christine.dayton@rfets.gov

Elizabeth Pottorff

Colorado Department of Public Health and

the Environment

email: etpottot@smtpgate.dphe.dstate.co.us

\section{Project Productivity}

Work was accomplished on schedule and within budget.

\section{Personnel Supported:}

LANL - Robert Roback (Postdoc), Steve Goldstein (Staff), and Mike Murrell (Staff)

USC - Richard Ku (Professor) and Shangde Luo (Staff)

\section{Publications:}

\section{A. Peer-Reviewed}

Ku, T. L., Luo, S., Leslie, B. W. and Hammond, D. E. Assessing radionuclide migration from natural analog studies: Response to McKinley and Alexander (1996). Radiochimica Acta $\underline{80}$, 219-223, 1998.

Luo, S., Ku, T. L., Roback, R., Murrell, M., and McLing, T. L., In-situ radionuclide transport and preferential groundwater flows at INEEL (Idaho): Decay-series disequilibrium studies. Geochimica et Cosmochimica Acta 64, no. 3, 2000.

B. Proceedings

Luo, S., Ku, T. L., Roback, R., Murrell, M., and McLing, T. L., Decay-series disequilibrium study of in-situ, long-term radionuclide transport in water-rock systems. Proceedings on Scentific Basis for Nuclear Waste Management XXIII, Material Research Society, 2000.

C. In Review 
Roback, R.C., Johnson, T.M., McLing T.L., Murrell, M.T., Ku, T. L, and Luo S., Preferential flow pathways and groundwater evolution in the Snake River Plain aquifer in the vicinity of the INEEL: constraints form ${ }^{234} \mathrm{U} /{ }^{238} \mathrm{U}$ and ${ }^{87} \mathrm{Sr} /{ }^{86} \mathrm{Sr}$ isotope ratios

Johnson, T.M., Roback, R.C., McLing, T.L., Bullen, T.D., DePaolo, D.J., Doughty, C., Hunt R.J., and Murrell, M.T., Groundwater "fast paths" in the Snake River Plain Aquifer: radiogenic isotope ratios as superior natural groundwater tracers

\section{Interactions}

A. Presentations at meetings, workshops, conferences, seminars

Roback Robert C., Murrell Michael, Nunn Andy, Johnson Thomas, McLing Travis, Luo Shangde and Ku Richard, "Groundwater mixing, flow-paths and water/rock interaction at INEEL: Evidence from uranium isotopes," Geological Society of America, Abstracts with Programs, v. 29, no. 6., 1997.

Murrell M. and Ku T. L., Characterization of contaminant transport using naturally occurring Useries disequilibria. DOE Environmental Management Science Program Workshop, Rosemont, IL, July 27-30, 1998, CONF-980736, Poster 179, p. 358-359.

Luo S., Ku T. L., Roback R., Murrell M., and McLing T., "Uranium-Series Disequilibria In Groundwater: Assessing Radionuclide Migration," 9th International Conference on Isotope Geology, Cosmochemistry and Geochronology, Aug. 21-26, Beijing, 1998.

Luo S., Ku T. L., Roback R., Murrell M., and McLing T., "Assessing in-situ radionuclide transport based on uranium-series disequilibrium in groundwater", Fall AGU Meeting, Dec. 6-10, 1998, San Francisco, EOS Trans. Amer. Geophys. Un. 79, F354, 1998.

Roback R. C., Murrell M. T., Nunn, A., Luo S., Ku T. L., and McLing T., "Uranium and thorium series isotopes in fractured rocks at the INEEL", Fall AGU Meeting, Dec. 6-10, 1998, San Francisco, EOS Trans. Amer. Geophys. Un. 79, F343, 1998.

Luo S., Ku T. L., Roback R., Murrell M., and McLing T.L., "Decay-Series Disequilibrium Study Of In-Situ, Long-Term Radionuclide Transport In Water-Rock Systems", MRS Fall Meeting, Nov. 29-Dec. 3, 1999, Boston, MRS 1999 Fall Meeting Abstract Volume, p. 734, 1999.

\section{B. Consultations to other laboratories and agencies}

\section{RFETS}

C. Collaborations

Tom Johnson (U of Illinois) and Travis McLing (INEEL) 


\section{Transitions:}

A. Describe cases where knowledge resulting from this effort was used by the DOE or other agencies

As discussed above, the demonstration of these capabilities at INEEL lead to work at RFETS through the Environmental Remediation department run at Rocky Flats and later by Regulators at the Colorado Department of Public Health and Environment. The EMSP project provided the opportunity and funding to focus a research capability on a DOE problem, to generate a focused set of results

B. List the research and the individual who made use of the research

Lane Butler

RFETS

Christine Dayton

RFETS

\section{Patents:}

None

\section{Future Work:}

Further refinement of our natural analog approach of evaluating the in situ migratory behavior of radioactive nuclides is needed. There is a need to produce a realistic model of radionuclide migration under unsaturated as well as saturated field conditions. Close coordination between the laboratory and the field experiments will ensure a rational basis for comparison between the two approaches. Laboratory efforts will also be directed toward improvement on the modeling of interfacial processes of dissolution-precipitation and adsorption-desorption across individual mineral. The role of colloids in nuclide transport needs evaluation, as does the role of water chemistry and rock mineralogy.

\section{Literature Cited:}

Ackerman, D. J., U. S. Geological Survey Water Resources Investigations Report 94-4257, Idaho Falls, Idaho, (1995).

Bartholomay, R. C., Orr, B. R., Liszewski, M. J., and Jensen, R. G., U. S. Geological Survey Water-Resources Investigations Report 95-4175, Idaho Falls, Idaho (1995).

Beasley, T. M., Dixon, P. R., and Mann, L. J., Environmental Science and Technology, v. 32, p. 2875-3881 (1998).

Bennett, C. M., U. S. Geological Survey Water-Resources Investigations Report 90-4067, Idaho Falls, Idaho (1990).

Knobel L. L., Cecil L., and Wood T. S., U. S. Geological Survey Open-File Report 95-748, Idaho Falls, Idaho (1995). 
Krishnaswami, S., Graustein, W. C., Turekian, K. K. and Dowd, J. F., Water Resour. Res. 18, p. 1663-1675 (1982).

Ku, T. L., Luo, S., Leslie, B. W., and Hammond, D. E, in Uranium-series disequilibrium: applications to earth, marine, and environmental sciences. eds. Ivanovich, M. and Harmon, R. S. Clarendon Press, Oxford, United Kingdom, p. 631-668 (1992).

Ku, T. L., Luo, S., Leslie, B. W., and Hammond, D. E., Radiochim. Acta 80, p. 219-223 (1998).

Leeman, W. P. \& Manton, W. I., Earth and Planetary Science Letters v. 11, p. 420-434 (1971).

Murphy, W. M., in Sixth EC Natural Analogue Working Group Meeting, Proceedings of an international workshop held in Santa Fe, New Mexico, USA, edited by H. von Maravic and J. Smellie (European Commission, EUR16761, 1996), p. 233-241.

Osmond, J. K. \& Cowart, J. B., 1992, Groundwater. in Uranium-series disequilibrium: applications to earth, marine, and environmental sciences. eds. Ivanovich, M. and Harmon, R. S. Clarendon Press, Oxford, United Kingdom, p. 290-333 (1992).

Welhan, J. A. and Reed, M. F., Geological Society of America Bulletin, v. 109, p. 855-868 (1997).

Wood, W., W. and Low, W. H, Geological Society of America Bulletin 97, p. 1456-1466 (1986).

Zukin, J. G., and Hammond, D. E., Ku, T. L, and Elder, W. A., Geochim. Cosmochim. Acta 51, 1719-1931 (1987).

\section{Feedback:}

More effort needs to be made by the Program Managers to include the Campus PI in the process of monthly and annual reporting, invitations to the yearly workshops, and to generally keep them better updated and included in the process.

\section{Appendices:}

\section{Appended preprints:}

A. Luo, S., Ku, T. L., Roback, R., Murrell, M., and McLing, T. L., In-situ radionuclide transport and preferential groundwater flows at INEEL (Idaho): Decay-series disequilibrium studies

B. Roback, R.C., Johnson, T.M., McLing T.L., Murrell, M.T., Ku, T. L, and Luo S., Preferential flow pathways and groundwater evolution in the Snake River Plain aquifer in the vicinity of the INEEL: constraints form ${ }^{234} \mathrm{U}^{238} \mathrm{U}$ and ${ }^{87} \mathrm{Sr}{ }^{86} \mathrm{Sr}$ isotope ratios

C. Johnson, T.M., Roback, R.C., McLing, T.L., Bullen, T.D., DePaolo, D.J., Doughty, C., Hunt R.J., and Murrell, M.T., Groundwater "fast paths" in the Snake River Plain Aquifer: radiogenic isotope ratios as superior natural groundwater tracers 